Bajrektarevic A.

\title{
Europe of Sarajevo 100 years later: Was history ever on holidays? (From WWI to www. 9/11 or 11/9?)
}

\begin{abstract}
Some 20 years ago the genocide of worst kind was taking place just one hour flight from Brussels. That time, assassination of different kind from the one of 1914 has enveloped Sarajevo. While massive European ignorance turned Bosnia (and the Union of different peoples - Yugoslavia) into a years-long slaughterhouse, the Maastricht dream was unifying the Westphalian world of the Old continent. Today, two decades later, Atlantic Europe is a political powerhouse (with two of three European nuclear powers, and two of five permanent members of the UN Security Council, $P-5)$, Central Europe is an economic powerhouse, Russophone Europe is an energy powerhouse, Scandinavian Europe is a bit of all that, and Eastern Europe is none of it. No wonder that as soon as serious external or inner security challenges emerge, the compounding parts of the true, historic Europe are resurfacing again. Formerly in Iraq (with the exception of France) and now with Libya, Sudan, Mali and Syria; Central Europe is hesitant to act, Atlantic Europe is eager, Scandinavian Europe is absent, Eastern Europe is bandwagoning, and Russophone Europe is opposing. Did Europe change (after its own 11/9), or it only became more itself?
\end{abstract}

Keywords: Europe, genocide, Bosnia, June-1914, unification, Westphalian Ummah, 9/11, geopolitics, civilization, Sarajevo.

$\mathrm{E}$ urope of June 1914 and of June 2014. Hundred years in between, two hot and one cold war. The League of Nations, Cristal Night, Eurosong and Helsinki Decalogue Coco Chanel, VW, Marshall Aid, Tito, Yuri Gagarin, Tolkien's troll, Berlin wall and Euro-toll Ideologies, purges, repeated genocides, the latest one coinciding with the Maastricht birth of the Union... a televised slaughterhouse and the Olympic city besieged for 1,000 days, just one hour flight from Brussels.

E non so più pregare

E nell'amore non so più sperare

E quell'amore non so più aspettare ${ }^{1}$

Key words in 1914: Jingoism, booming trade and lack of trust, assassination, imminent collision, grand war. 100 years later; Europe absorbed by the EU project,

\footnotetext{
1 Taken from the lyrics of Miss Sarajevo, the song written by Bono Vox of U-2 and Luciano Pavarotti, and performed together with Brian Eno (1994). This instant radio-hit was inspired by the true events, when Sarajevens - as a form of urban protest to the world indifferent to their suffering - organized the Miss of Besieged Sarajevo beauty contest only few hundred meters from the battlefield lines. Translated from Italian, this line states: “...And I don't know how to pray anymore / and in love I don't know how to hope anymore / and for that love I don't know how to wait anymore..."
}

demographic and economic decline, chauvinism reloaded ... Twisting between the world of (Gavrilo) PRINCIP and global village of (instant) MONETISATION (of everything and everyone)... Are our past hundred years an indication of what to expect throughout this century?! What is our roadmap?! Is it of any help to reflect on the Sarajevo event of June $28^{\text {th }}, 1914$ which has finally fractured a fragile equilibrium of La Belle Èpoque, and set the Old Continent (and its world) into the series of motions that lasted for almost a century, before ending with the unique unionistic form of today's Europe?

\section{Four men leading one man bound One man whom the four men hound One man counted bound and led One man whom the four men dread ${ }^{2}$}

The following lines are not a comprehensive account on all of the events. Rather interpretative by its nature, this is a modest reminder of what Europe used and still tends to be, despite all our passions and hopes, visions and targets, institutions and instruments.

\footnotetext{
2 Mak - Mehmedalija Dizdar, Bosnian poet of the modern generation. The quotation is actually an ending part of his poem: "A Note about the Five" (trans. Francis R. Jones), from his "Stone Sleeper" poetry collection (1966-71) Svjetlost, Sarajevo.
} 


\section{Bajrektarevic A.}

\section{$* * * * *$}

Is the EU a post-Westphalian conglomerate and post-Metternich concert of different Europes, the world's last cosmopolitan enjoying its postmodern holiday from history $?^{3}$ Is that possibly the lost Atlántida or mythical Arcadia- a Hegelian end of history world? Thus, should this OZ be a mix of the locally domesticated Marx-Engels grand utopia and Kennedy's dream-world "where the weak are safe and the strong are just"? Or, is it maybe as Charles Kupchan calls it a 'postmodern imperium' (exhorting its well-off status quo by notoriously exporting its transformative powers of free trade dogma and human rights stigma ${ }^{4}-\mathrm{a}$ modified continuation of colonial legacy when the European conquerors, with fire and sword, spread commerce, ${ }^{5}$ Christianity and civilization overseas), a kind of 'new Byzantium', or is that more of a Richard Young's declining, unreformed and rigid Rome? Hence, is this a post-Hobbesian (yet, not quite a Kantian) world, in which the letzte Mensch expelled Übermensch? Could it be as one old graffiti in Prague implies: $\mathrm{EU}=\mathrm{SU}^{2}$ ? Does the EU-ization of Europe equals to a restoration of the universalistic world of Rome's Papacy? Is the Union a Leonard's runner of the $21^{\text {st }}$ century, or is it perhaps Kagan's 'Venus'-gloomy and

\footnotetext{
3 One of the greatest historians of our age, Sir Toynbee, gives an interesting account of our civilizational vertical. He clas-sifies as many as nineteen major civilizations: Egyptian, Andean, Sinic, Minoan, Sumerian, Mayan, Indic, Hittite, Hellenic, Western, Orthodox Christian/ Russian, Far Eastern, Orthodox Christian/ main body, Persian, Arabic, Hindu, Mexican, Yucatec, and Babylonic). Further on, there are - as he calls them - four abortive civilizations (Far Western Christian, Far Eastern Christian, Scandinavian, Syriac) and five arrested civilizations (Polynesian, Eskimo, Nomadic, Ottoman, Spartan). Like to no other continent, majority of them are related (originating from or linked) to European proper.

4 Lately, it looks like a Gay-rights Jihad at many places. The non-selective, but massive push without premeditation on the key issue here: whether homosexuality should be either tolerated behavior or promoted life-style, has to be urgently revisited and (re-)calibrated. As it stands now, this Gay-rights Jihad neither serves the human/behavioristic rights nor a worrying birth-rates decline. The European demographics is far more of a serious and urgent socio-economic problem, as it is closely related to the emotional-charge inflammable issues of migration and integration, and by it triggered (to say: justified) right-wing anti-politics.

5 Is globalization the natural doctrine of global hegemony? Well, its main instrument, commerce -as we know - brings people into contact, not necessarily to an agreement, even less to mutual benefits and harmony...Or, "If goods cannot cross borders, armies will" is the famous saying of the XIX century French economist Frederic Bastiat, so often quoted by the longest-ever serving US Secretary of State Cordell Hull.
}

opaque world, warmer but equally distant and unforeseen like 'Mars'?

Is this Brussels-headquartered construct, the $20^{\text {th }}$ century's version of Zollverein with standardized tariffs and trade, but of an autonomous fiscal policy and politics? Thus, is the EU a political and economic re-approachment of sovereign states or maybe just an(other) enterprise of the borderless financial capital? Ergo, would that be a pure construct of financial oligarchy whose invisible hand tacitly corrupted the Maastricht Treaty as to web-up a borderless, limitless, wireless and careless power hub, while at the same time entrenching, silencing and rarefying labour within each nation state?

Is this a supersized Switzerland (ruled by the cacophony of many languages and enveloped in economic egotism of its self-centered people), with the cantons (MS, Council of EU) still far more powerful than the central government (the EU Parliament, Brussels' Commission, ECJ), while Swiss themselves -although in the geographic heart of that Union - stubbornly continue to defy any membership. Does it really matter (and if so, to what extent) that Niall Ferguson wonders: “...the EU lacks a common language, a common postal system, a common soccer team (Britain as well, rem. A.B.) even a standard electric socket..."? Kissinger himself was allegedly looking for a phone number of Europe, too. Baron Ridley portrayed the Union as a Fourth Reich, not only dominated by Germany, but also institutionally Germanized. Another conservative Briton, Larry Siedentop, remarked in his Democracy in Europe that it is actually France who is running the EU 'show', in the typical French way - less than accountable bureaucracy that prevents any evolution of the European into an American-style United States. Thus, Siedentop's EU is more of a Third Bonapartistic Empire than possibly a Fourth German Reich. The Heartland or Rimland?

After all, is the Union yet another virtue out of necessity, as Brzezinski claimed, that after centuries of colonial overstretch and of mutual destructions (between protagonists in close geographic proximity), Eu-

\footnotetext{
6 "No venue has been created in which an EU-wide public opinion might be formed... European Parliament elections are not truly European because they are 27 different elections with different electoral systems after campaigns in which national issues predominate... Under present procedures, both the President of the European Commission and the President of the European Council are selected in private meetings of heads of governments.., says former Irish Prime Minister John Bruton. Bruton, J. (2013), How real is the danger of an EU collapse?, EU Journal Europe's World 23(13) 2013, Brussels.

Ferguson, N. (2005) Colossus - The Rise and Fall of the American Empire, Penguin Books (page 255).
} 


\section{Political science}

rope irreversibly lost its demographic, economic and politico-military importance, and that the early EU was more of an attempt to rescue a nation state than it was the quest for a true enterprise of the European Community building?

Despite different names and categorizations attached, historical analogies and descriptions used, most scholars would agree upon the very geopolitical definition of the EU. It is, thus, predominantly defined as a grand re-approachment of France and Germany after WWII, culminating in the Elysée accords of 1961. An interpretation of this instrument is rather simple: a bilateral peace treaty through achieved consensus by which Germany accepted a predominant French say in political affairs of EU/Europe, and France - in return - accepted a more dominant German say in economic matters of EU/Europe. All that tacitly blessed by a perfect balancer- Britain, attempting to conveniently return to its splendid isolation from the Continent in the post-WWII years. Consequently, nearly all scholars would agree that the Franco-German alliance actually represents a geopolitical axis, a backbone of the Union.

But, what does it mean, precisely? Why Germany, and why France? And why, besides the geographic (e.g. north-south, Nordic-Mediterranean) and political (e.g. the EU and non-EU Europe; the 'good old' West and new 'transitioning' East, or old EU 15 and new EU 13, or the Paris treaty core-6, etc.) categorization, do we need to take an additionally due look at the classification of historical Europes? ${ }^{8}$

\section{Una hysteria importante}

History of Europe is the story of small hysteric/xenophobic nations, traditionally sensitive to the issue of ethnic, linguistic, religious, and behavioristic otherness. ${ }^{9}$ If this statement holds the truth, then we refer

\footnotetext{
8 Classic division on north and south in the European newspeech originating from the London City and Frankfurt's banking circles would be pigs vs. wings (indebted south: PIGS - Portugal, Italy, Greece and Spain vs. prosperous north: WINGS - West, Industrial North, Germany and Scandinavia).

9 Enveloped in its own myopia of economic egoism, Europeans are in fact digging and perpetuating defensive self-isolation. While falling short to constructively engage its neighborhood (but not conveniently protected by oceans like some other emigrantreceiving countries), Europeans constantly attract unskilled migrants. The US, GCC, Far East, Australia, Singapore, lately even Brazil, India, or Angola - all have enormously profited from the skilled newcomers. Europe is unable to preserve, protect and promote its skilled migrants. Simply, European history of tolerance of otherness is far too short for it, while the legacies of residual fears are deep, lasting and wide.
}

to events before and after the Thirty Years' War in general and to the post-Napoleonic Europe in particular. Political landscape of today's Europe had been actually conceived in the late $14^{\text {th }}$ century, gradually evolving to its present shape. The universalistic world of the Holy Roman Empire and Papacy is steadily contested by the explicitly confronta-tional or implicitly dismissive political entities, be it ideologically (the Thirty Years' War culminating with the Peace of Westphalia) or geopolitically (Grand Discoveries and the shift of the gravity center westwards). The early round of colonizers, the two Iberian empires of Spain and Portugal, are the first entities that emerged, followed by France, Holland, England and Denmark. (Belgium too, although it appeared as a buffer zone at first - being a strategic depth, a continental prolongation of England for containment of Central Europeans, Dutch and Scandinavians from the open sea, while later on also becoming a strategic depth of France for balancing Britain and containment of Denmark and Prussia.)

Engulfed with the quest of the brewing French revolution for the creation of a nation state, these colonizers, all of them situated on the Atlantic flank of Europe, have successfully adjusted to the nation-state concept. Importantly, the very process of creation/formation of the nation-state has been conducted primarily on linguistic grounds since religious grounds were historically defeated once and for all by the Westphalia: ${ }^{10}$ All peoples talking the Portugo-phone dialects in one state, all Hispanophone dialects in another state, all Francophone dialects in the third state, etc. ${ }^{11}$ This was an easy cut for peripheral Europe, the so-called old colonizers on the Atlantic flank of Europe, notably for Portugal, Spain, France, England, Denmark, the Netherlands, and Sweden.

Although geopolitically defeated and ideologically contained by the Vienna Congress and its instrument: the Holy Alliance of Eastern Conservative Courts, the very idea of a nation-state remained appealing. Once the revolutionary 1848 ousted the principal guardian

\footnotetext{
10 To be more accurate: Westphalia went beyond pure truce, peace and reconciliation. It re-confirmed existence of western Christianity's Ummah. Simply, it only outlawed meddling into the intra-western religious affairs by restricting that-time absolute Papal (interpretative) powers. From that point of view, Westphalia was not the first international instrument on religious freedoms, but a triumph of western evangelic unity, which later led to the strengthening of western Christianity's supremacy intercontinentally.

11 All modern European languages that are taught in schools today, were once upon a time actually a political and geographic compromise of the leading linguists, who - through adopted conventions - created a standard language by compiling different dialects, spoken on the territory of particular emerging nation-state.
} 


\section{Bajrektarevic A.}

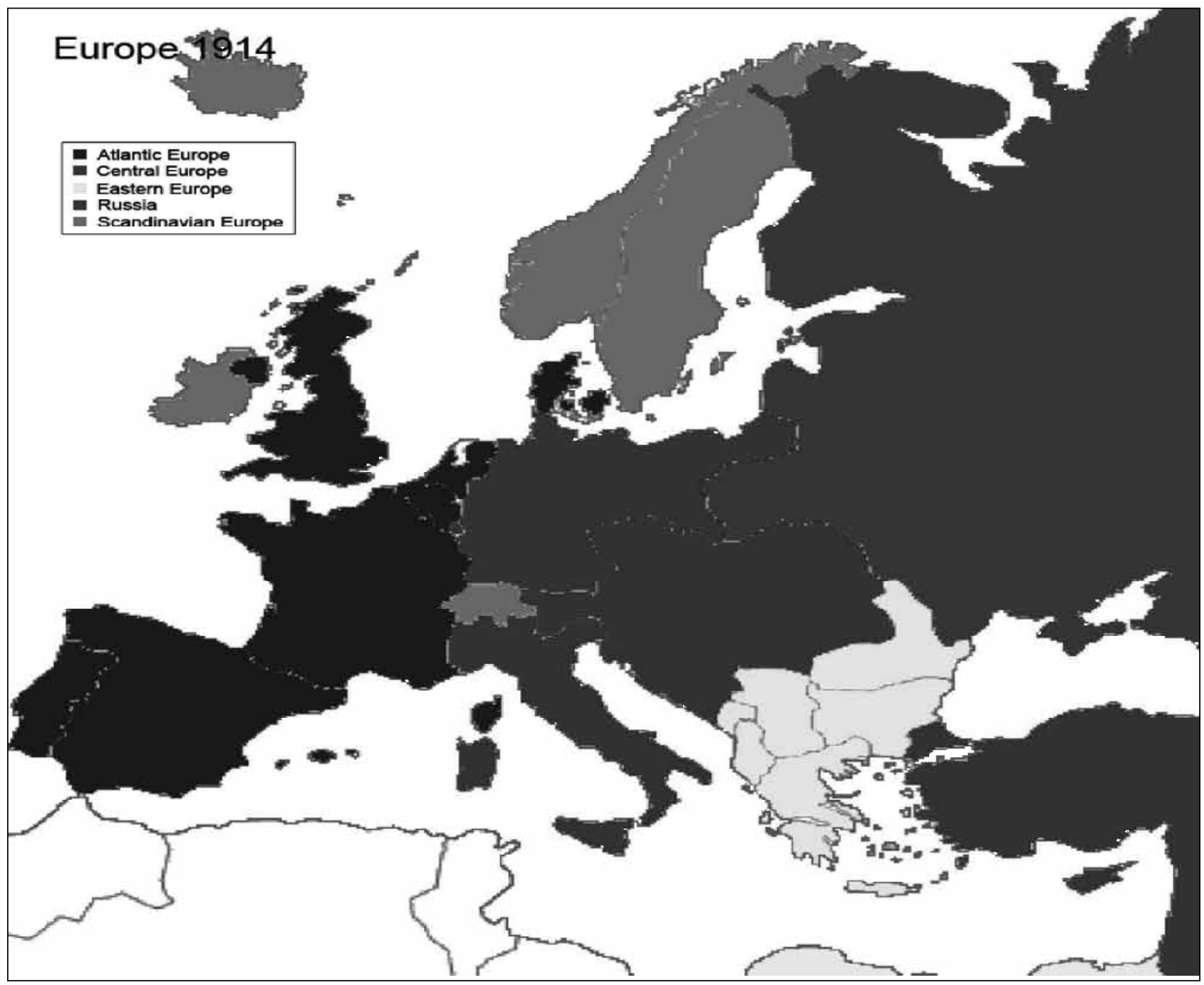

of feudalism in Europe, Metternich, the suppressed concept got further impetus. And, the revolutionary romance went on... Hence, the very creation of central European nation-states was actually enhanced by Napoleon III. The unification of Italophones was his, nearly obsessive, inten-tional deed (as he grew up in Nice with Italian Carbonari revolutionists who were fighting papal and Habsburg's control over the northern portions of today's Italy). Conversely, the very unification of Germanophones under the Greater Prussia was his non-intentional mis-chief, with the two subsequently emerging 'by-products'; modern Austria (Germanspeaking core assembled on the ruins of mighty multinational and multi-linguistic empire) and modern Turkey (Turkophone core on the ruins of mighty multiracial and multi-linguistic empire).

Despite being geographically in the heart of $\mathrm{Eu}-$ rope, Switzerland remained a remarkably stable buffer zone: Highly militarized but defensive and obsessively neutral, economically omnipresent yet financially secretive, it represents one confederated state of two confronting versions of western Christianity, of three ethnicities and of four languages. Absent from most of the modern European politico-military events - Switzerland in short - is terra incognita.

Historically speaking, the process of Christianization of Europe used as the justification tool to pacify the invading tribes, that demolished the Roman Empire and brought to an end the Antique age, was running parallel on two tracks. One of them was conducted by the Roman Curia/Vatican and its hammer: the Holy Roman Empire. The second was run by the cluster of Rusophone Slavic Kaganates, who receiving (the orthodox or true/authentic, so-called Eastern version of) Christianity from Byzantium, and past its collapse, have taken over a mission of Christianization, while 


\section{Political science}

forming its first state of Kiev Russia (and thereafter, its first historic empire). So, to the eastern edge of Europe, Russophones have lived in an intact world of universalism for centuries: one empire, one Tsar, one religion and one language. ${ }^{12}$

Everything in between Central Europe and Russia is Eastern Europe, rather a historic novelty on the political map of Europe. Very formation of the Atlantic Europe's present shape dates back to $14^{\text {th }}-15^{\text {th }}$ century, of Central Europe to the mid-late $19^{\text {th }}$ century, while a contemporary Eastern Europe only started emerging between the end of WWI and the collapse of the Soviet

12 Annotated from one of my earlier writings, it states as following: “...Early Russian state has ever since expanded north/ northeast and eastward, reaching the physical limits of its outreach by crossing the Bering straits (and the sale of Russian Alaska to the USA in 1867). By the late 17 th and early 18 th century, Russia had begun to draw systematically into European politico-military theatre. (...) In the meantime, Europe's universalistic empire dissolved. It was contested by the challengers (like the Richelieu's France and others-geopolitical, or the Lutheran/Protestant ideological), and fragmented into the cluster of confronted monarchies, desperately trying to achieve an equilibrium through dynamic balancing. To this similar political process will affect Russian universal empire only by late 20th century, following the Soviet dissolution. (...) Not fully accepted into the European collective system before the Metternich's Holy Alliance, even had its access into the post-Versailles system denied, Russia was still not ignored like other peripheral European power. The Ottomans, conversely, were negated from all of the security systems until the very creation of the NATO (Republic of Turkey). Through the pre-emptive division of Poland in the eve of WWII, and successful campaigns elsewhere in Eastern Europe, Russia expanded both its territory and its influence westwards. (...) An early Soviet period of Russia was characterized by isolated bilateral agreements, e.g. with Germans, Fins, Japanese, etc. The post WWII days have brought the regional collective system of Warsaw Pact into existence, as to maintain the communist gains in Europe and to effectively oppose geopolitically and ideologically the similar US-led block. Besides Nixon's reapproachment towards China, the collapse of the Soviet Union was the final stage in the progressive fragmentation of the vast Sino-Soviet Communist block (that dominated the Euroasian land mass with its massive size and centrality), letting Russia emerge as the successor. The sudden Soviet break-up, however, was followed by the cultural shock and civil disorder, painful economic crisis and rapidly widening disparities, as well as the humiliating wars in Caucasus and elsewhere, since the centripetal and centrifugal forces of integration or fragmentations came into the oscillatory play. Between 1989 and 1991, communist rule ended in country after country and the Warsaw Pact officially dissolved. Subsequently, the GorbachevJeltsin Russia experienced the greatest geopolitical contraction of any major power in the modern era and one of the fastest ever in history. Still, Gorbachev-Jeltsin tandem managed to (re-)brand themselves domestically and internationally - each got its own label of vodka..." (Verticalization of Historical Experiences: Europe's and Asia's Security Structures - Structural Similarities and Differences, Crossroads - the Macedonian Foreign Policy Journal, 4 (1), page 111-112, M-MFA 2008)
Union - meaning, less than 100 years, in best cases. No wonder that the dominant political culture of the Eastern Europeans resonates residual fears and reflects deeply insecure small nations. Captive and restive, these are short in territorial depth, in demographic projection, in natural resources and in a direct access to open (warm) seas, after all, short in historio-cultural verticals and in a bigger picture-driven long-term policies. They are exercising the nationhood and sovereignty from quite a recently. Therefore, they are often dismissive, hectic and suspectful, nearly neuralgic and xenophobic, with frequent overtones.

The creation of a nation-state (on linguistic grounds) in the Atlantic, Scandinavian and Central Europe was relatively a success-story. However, in Eastern Europe it repeatedly suffered setbacks, culminating in the Balkans, Caucasus and the Middle East, but also evident in the central or Baltic part of Eastern Europe. ${ }^{13}$

\section{Keeping the center soft}

Ever since Westphalia, Europe maintained the inner balance of powers by keeping its core section soft. Peripheral powers like England, France, Denmark, (Sweden and Poland being later replaced by) Prussia, the Ottomans, Habsburgs and Russia have pressed and kept the center of continental Europe as their playground. At the same time, they kept extending their possessions overseas or, like Russia and the Ottomans, over the land corridors deeper into Asian and MENA proper. ${ }^{14}$ Once Royal Italy and Imperial Germany had appeared, the geographic core 'hardened' and for the first time started to politico-militarily press onto peripheries. This new geopolitical reality caused a big security dilemma lasting from the 1814 Vienna congress up to Potsdam conference of 1945 , being re-actualized again with the Berlin Wall destruction: How many Germanies and Italies should Europe have to preserve its inner balance and peace ${ }^{15}$ As the late-comers the Cen-

\footnotetext{
13 Many would say that, past the peak Ottoman times, the aggressive intrusion of Atlantic Europe with its nation-state concept, coupled with Central Europe's obsessive control and surveillance drive, has turned a magnificently mild and tolerant lands and intellectual exchange-corridors of southeastern Europe and the Near East into a modern day Balkan powder keg. Miroslav Krleza famously remarked: "It was humans who transformed our swine to a pig."

14 Serves as a curios fact that the first border agreement ever signed by Mexico with any of its neighbors was with Tsarist Russia (delimitation of proper stretching over today's western coast of Canada and the US state of Washington).

15 At the time of Vienna Congress, there were nearly a dozen of Italophone states and over three dozens of Germanophone enti-
} 


\section{Bajrektarevic A.}

tral Europeans have faced the overseas world, clearly divided into spheres of influence.

In very simplified terms, we can say that from the perspective of European belligerent parties, both world wars were fought between the forces of status quo and the challengers to this status quo. The final epilogue in both wars was that Atlantic Europe has managed to divert the attention of Central Europeans from itself and its vast overseas possessions onto Eastern Europe, and finally towards Russia. ${ }^{16}$ Just to give the most illustrative of many examples; the Imperial post-Bismarck Germany has carefully planned and ambitiously grouped its troops on the border with France. After the assassination of the Austrian Archduke in Sarajevo (28 June 1914), Europe was technically having a casus belli - as the subsequent mutually declared war between all parties quickly followed this assassination episode and the Austrian ultimatum to Serbia. However, the first armed engagement was not taking place on the southeastern front, as expected - between the Eastern belligerent parties such as Austria, Serbia, Russia, the Ottomans, Greece, Bulgaria, etc. The first military operations of WWI were actually taking place in the opposite, northwest corner of Europe and only months later. It was in German penetration of Belgian Ardennes. Still, the very epilogue of la Grande Guerra was such that a single significant territorial gain of Germany was achieved only in Eastern Europe. Despite a colossal 4-years long military effort, the German western border remained nearly unchanged. ${ }^{17}$

The end of WWI did not bring much change. The accords de paix - Versailles treaty was an Anglo-French triumph. These principal Treaty powers, meaning: Atlantic Europe, invited Germany to finally join the League of Nations in 1926, based on the 1925 Treaty of Locarno. By the letter of this treaty, Germany obliged itself to fully respect its frontiers with Belgium and France (plus demilitarized zone along the Rhine) with the unspecified promise to arbitrate before pursuing

ties -34 western German states +4 free cities (Kleinstaaterei), Austria and Prussia. Potsdam conference concludes with only three Germanophone (+ Lichtenstein + Switzerland) and two Italophone states (+ Vatican).

16 Why did the US join up Atlantic Europe against Central Europe in both WWs? Simply, siding up with Central Europe would have meant politico-military elimination of Atlantic Europe once and for all. In such an event the US would have faced a single European confrontation-potent block to engage with sooner or later, and would have lost an interfering possibility of remaining the perfect balancer. The very same balancer role, the US inherited from the declining Britain.

V.I. Lenin leaves Switzerland in April 1917, and is heading to Russia by train (in the sealed off wagon) crossing all over Germany - a self-telling episode of the WWI. any change of its borders with Czechoslovakia and Poland. The same modus operandi applied to the Austrian borders with Italy, Yugoslavia, Hungary and Czechoslovakia. The Locarno accord actually instrumentalized two sorts of boundaries around Central Europe (Germany-Austria): strict, inviolable ones towards Atlantic Europe; but semipermeable and soft towards Eastern Europe. ${ }^{18}$ That is how the predominant player from Central Europe, Germany, was accepted to the League, a collective system which the Soviet Russia (meaning: Rusophone Europe) was admitted to only a decade later (1934).$^{19}$ Soon after, this double standard sealed-off a faith of many in Europe and beyond.

In fact, the 1930s were full of public admirations of and frequent official visits to an Austrian-born Hitler. It was not only reserved for the British royal family (e.g. Edward VIII), but for many more prominents from both sides of the Atlantic. By 1938 in Munich, this 'spirit of Locarno' has been confirmed in practice when French President Daladier and British PM Chamberlain (Atlantic Europe) jointly paid a visit to Germany and gave concessions - practically a free hand - to Hitler and Mussolini (Central Europe) on gains in Eastern Europe. Neither Atlantic Europe objected to the pre-Munich solidification of Central Europe: Hitler-Mussolini pact and absorption of Austria, following a massive domestic Austrian support to Nazism of its 890,000 members of the Nazi party as well as a huge ring of sympathizers. By brokering the Ribbentrop-Molotov non-aggression deal between Berlin and Moscow, but only a year after the Munich-shame - in 1939 (including the stipulations on Finland, Baltic states and Poland), Stalin desperately tried to preempt the imminent: A horror of an uncontrolled expansion of Central onto Eastern Europe and closer to Russia, something that was already largely blessed and encouraged by Atlantic Europe. ${ }^{20}$

18 Farce or not, history nearly repeated itself to the last detail in early 1990s. The western frontiers of Central Europe remained intact, while the dramatic change took place to its East. Besides Anschluss of Eastern Germany by the Western one, borders there remained the same, but many former neighbors have one by one disappeared for good from the political map.

19 The Cold War era has prevented any comprehensive scientific consensus. The unbiased, de-ideologized and objective view on the WWII was systematically discouraged. Soviets consistently equated Nazism and imperialism while the US, for its part, equated fascism and communism. Until this very day, we do not have a full accord on causes and consequences of events in years before, during and after the WWII.

20 We should keep in mind that for the very objective of lebensraum policy (character and size of space needed for Germanophones to unhindered, live and prosper), the Jews, Roma and behavioristic minorities were the non-territorial obstacle. How- 


\section{Political science}

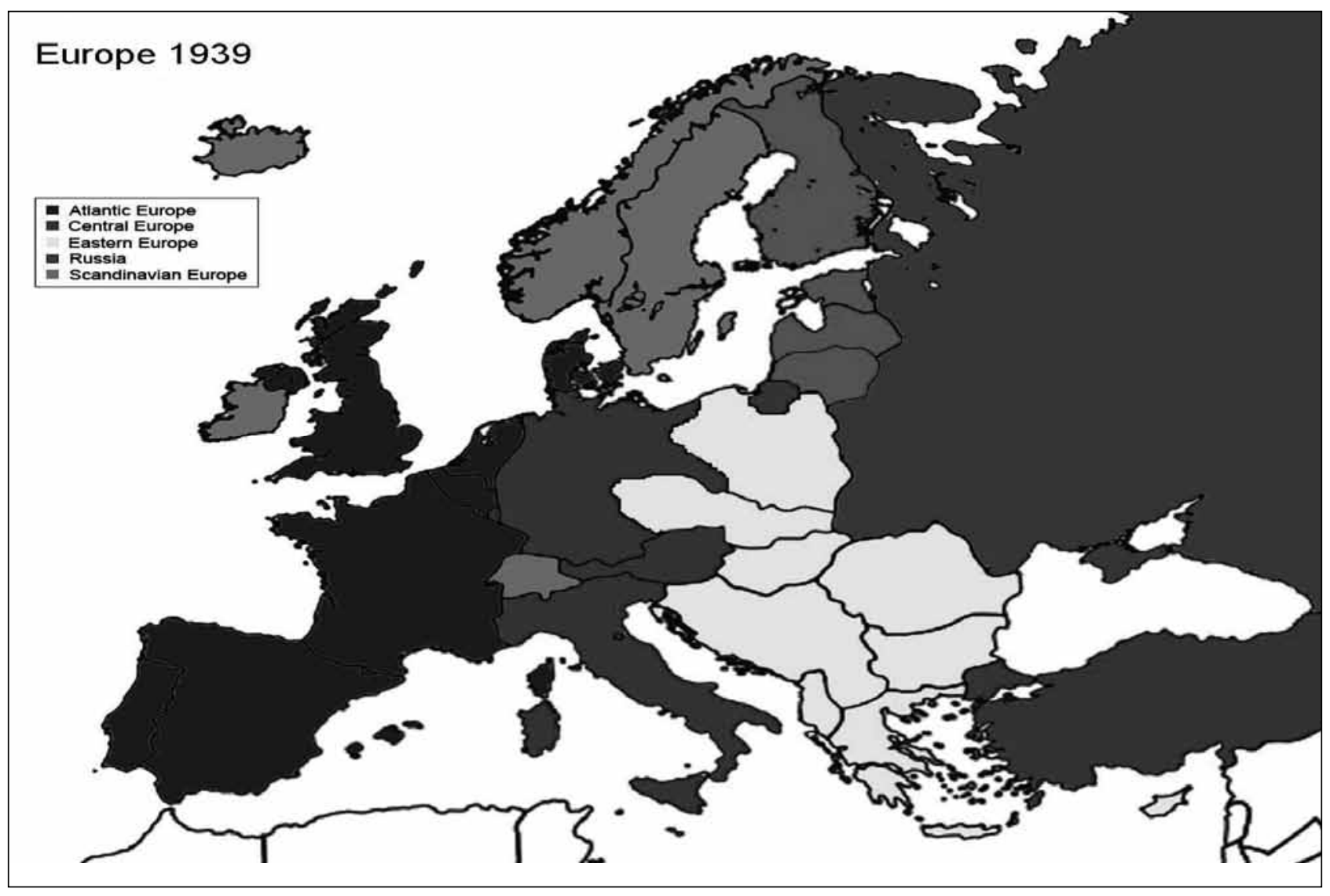

For some 300 years, Russia and the Ottomans have fought series of bitter wars over the control of the Black Sea plateau and Caucasus - sectors, which both sides (especially the Ottomans) have considered as geopolitically pivotal for their existence. Still, neither party has ever progressed at the battlefield as to seriously jeopardize the very existence of the other. However, Russia has experienced such moves several times from within Europe. Three of them were critical for the very survival of Russia and the forth was rather instructive: the Napoleonic wars, Hitler's Drang nach Osten, the so-called "contra-revolutionary" intervention, ${ }^{21}$ and finally the brief but deeply humiliating war with Poland (1919-21).

ever, Slavs and their respective Slavic states in Eastern Europe were the prime territorial target of Hitler-led Central Europe's 'final solution'. Therefore, no wonder why so much fifth column among Slavs. For the speeding and smoothening of the lebensraum objective, Quisling was needed as PM in Norway, but Slavic quisling-elites in each and every of that time major Slavic state - useful idiots in Poland, in Ukraine, in Czechoslovakia, in Yugoslavia, in Bulgaria, etc.).

${ }_{21}$ The 6-year-long insurgencies (largely financed and inspired by Western Europe as an overt 'regime change' intervention) at
Small wonder, that in 1945, when Russians - suffering over 20 millions of mostly civilian casualties and by far the heaviest continental burden of the war against Nazism - arrived on wings of their tanks and ideology to Central Europe, they decided to stay. Extending their strategic depth westwards-southwestwards, and fortifying their presence in the heart of Europe, ${ }^{22}$ was morally

the time of the young Bolshevik Russia that saturated the country (bringing the unbearable levels of starvation and hunger up to cases of cannibalism), took away 5 million mostly civilian lives, and set the stage for 'red terror'.

22 With the politico-military settlement of the Teheran and Yalta Conference (1943), and finally by the accord of the Potsdam Conference (1945), the US, UK and the SU unanimously agreed to reduce the size of Germany by $25 \%$ (comparable to its size of 1937), to recreate Austria, and to divide both of them on four occupation zones. The European sections of the Soviet borders were extended westwards (as far as to Kaliningrad), and Poland was compensated by territorial gains in former Eastern Prussia/ Germany. The pre-WWII inclusion of the three Baltic republics into the Soviet Union was unanimously confirmed by the Americans and Britons in Potsdam, too. Practically, Russians managed to eliminate Germany from Eastern Europe (and of its access to central and eastern portions of Baltic, too), and to place it closer to the Atlantic Europe's proper. 


\section{Bajrektarevic A.}

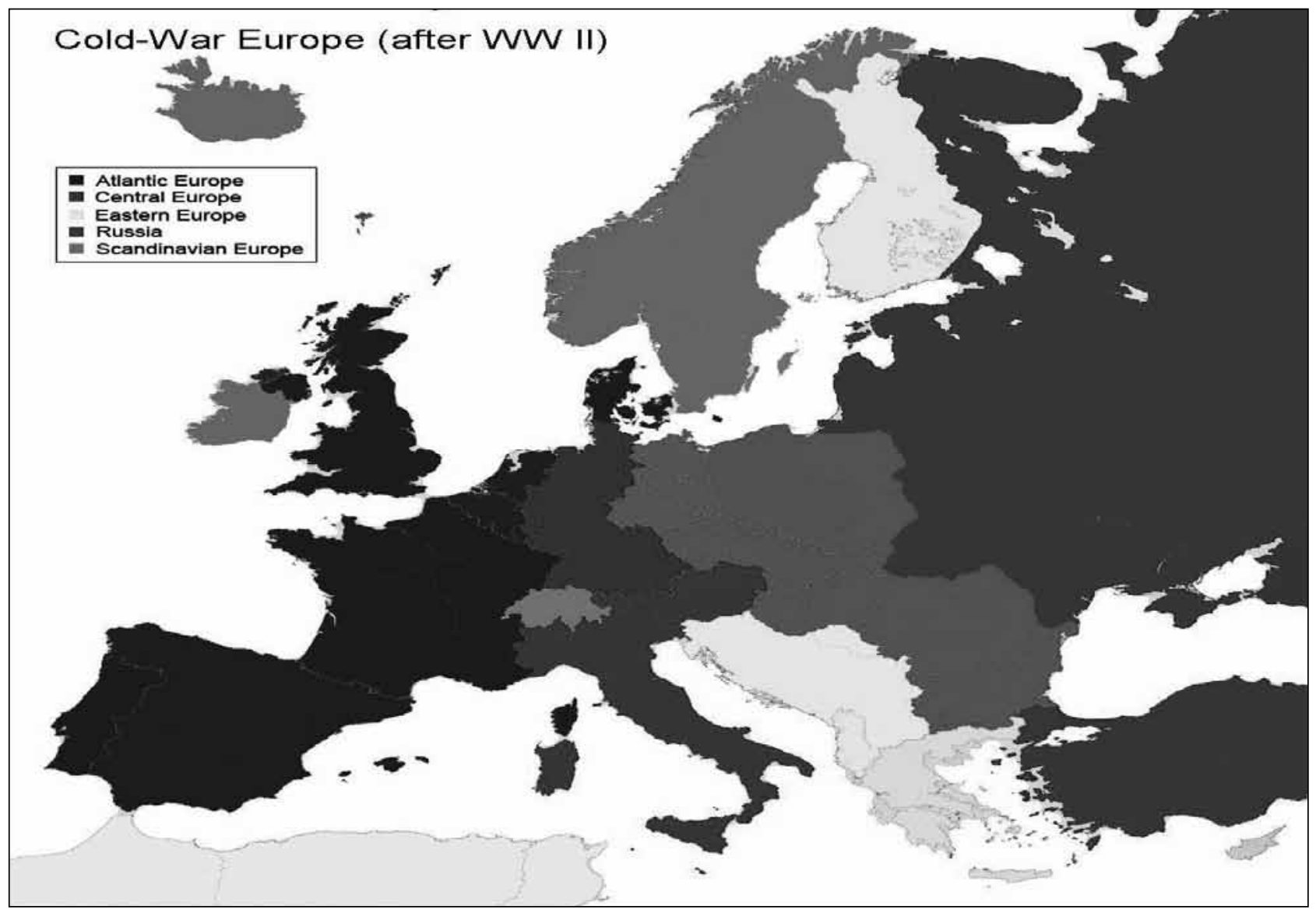

an occupation. Still, it was geopolitically the single option left, which Stalin as a ruthless person but an excellent geo-strategist perfectly understood. Just a quick look at the geographic map of Europe would show that the low-laying areas of western Russia, Belorussia, Ukraine and Eastern Europe are practically non-fortifiable and indefen-sible. Their topography exposes the metropolitan area and city of Moscow to an extreme vulnerability. So, the geostrategic dictatum is that in absence of any deep canyon, serious ridge or mountain chain, the only protection is either a huge standing army (expensive and badly needed in other corners of this vast country) and/or an extension of the strategic depth.

In a nutshell, we can say that the very epilogue of both WWs in Europe was a defeat of Central Europe (challenger of status quo) against Atlantic Europe (status quo defender), with the relatively absent, neutral Scandinavian Europe, of Eastern Europe being more an object than a subject of these mega-confrontations, and finally with a variable success of Russia.

Finally, back to Franco-German re-approachment: This is far more than just a story about the two countries signing d'accord. It truly marked a final decisive reconciliation of two Europes, the Atlantic and Central one. The status quo Europe has won on the continent but has soon lost its overseas colonies. Once realizing it, the road for 'unification' of the equally weakened protagonists in a close proximity was wide open. ${ }^{23}$ This is the full meaning of the 1961Elysée.

\section{Europe of Genocide and of Unification - Happy EU to You!}

The collapse of the Soviet Union marked a loss of the historical empire for Russia, but also a loss of geopolitical importance of nonaligned, world-wide respected

23 Nowadays, from the safe time-distance, it is easy to claim that the portion of Europe under Americans was of considerably better fortune than a part under the Soviet influence. Interestingly enough, the opposite situation was elsewhere: India - Pakistan, Vietnam - the Philippines, Cuba - Colombia, Egypt - Saudi Arabia, Ghana - Liberia. That means that the intra-European differences are beyond pure American-Russian influences, and therefore far more significant. Proof? The standard-of-living difference between London and Bucurest or Paris and Sofia today is of the same -or even wider - distance than it was some 40 years ago. 


\section{Political science}

Yugoslavia, ${ }^{24}$ which shortly after burned itself in series of brutal genocidal, civil war-like ethnical cleansings. The idea of different nations living together and communicating in different languages in a (con-)federal structure was (though imperfect) a reality in Yugoslavia, but also a declared dream of the Maastricht Europe. Moreover, this country was the only truly emancipated and indepen-dent political entity of Eastern Europe and one of the very few in a whole of the Old Continent. Despite the post-Cold War, often pre-paid, rhetorics that Eastern Europe rebelled against the Soviet domination in order to associate itself with the West, the reality was very different. Nagy's Hungary of 1956, Dubček's Czechoslovakia of 1968 and (pre-)Jeruzelski Poland of 1981 dreamt and fought to join a liberal Yugoslavia, and its internationally declared $3^{\text {rd }}$ way!

By 1989-90, this country still represented a hope of full emancipation and real freedom for many in the East. How did the newly created EU (Atlantic-Central Europe axis) react? At least tolerating (if not eager to support), or actively eliminating the third way of Yu-

24 Yugoslavia was by many facets a unique European country: No history of aggression towards its neighbors, with the high toleration of otherness. Yugoslav peoples were one of the rare Europeans who resolutely stood up against fascism, fighting it in a full-scale combat and finally paying it with $12 \%$ of its population in the 4-years war. (Relative to the 1939 size of state territory and incumbent population within, the top WWII fatalities were suffered by Poland - 18\%, the Soviet Union - 15\%, Yugoslavia $12 \%$, III Reich/Germany - 10\%. For the sake of comparison, the Atlantic rim suffered as follows: France $-1,3 \%$, UK -0,9\%, the US - 0,3\%.) Yugoslavs also firmly opposed Stalinism right after the WWII. Bismarck of southern Slavs - Tito doctrinated the socalled active peaceful coexistence after the 1955 Bandung southsouth conference, and assembled the non-Aligned movement (NAM) in its founding, Belgrade conference of 1961. Steadily for decades, the NAM and Yugoslavia have been directly tranquilizing the mega confrontation of two superpowers and satellites grouped around them (and balancing their irresponsible calamities all over the globe). In Europe, the continent of the sharpest ideological divide, with practically two halves militarily confronting each other all over the core sectors of the continent, and with its southern flank of Portugal, Spain and Greece (and Turkey sporadically) run by the military Juntas, Yugoslavia was remarkably mild island of stability, moderation and wisdom. Domestically, Yugoslavia had a unique constitutional setup of a strictly decentralized federation. Although being a formal democracy in its political life, many aspects of its social and economic practices as well as largely enjoyed personal freedoms and liberties featured the real democracy. The concept of self-management (along with the Self-managing Interest Community model) in economic, social, linguistic and cultural affairs gained a lot of external attention and admiration in the 1960s, 1970s and 1980s. Still, there was neither enough sympathies nor mercy in the towards-EU-heading Europe, to save either the Yugoslav people from an immense suffering or the symbol that this country represented domestically and internationally. goslavia? It responded to the Soviet collapse in the best fashion of a classic, historical nation-state, with the cold calculi of geopolitical consideration deprived of any ideological constrains. It easily abandoned altruism of its own idea by withdrawing its support to the reformist government of Yugoslavia and basically sealed-off its faith. Intentionally or not, indecisive and contradictory political messages of the Maastricht-time EU - from the explicate encouragement of separatism, and then back to the full reconfirmation of the territorial integrity and sovereignty of Yugoslavia - were bringing this multinational Slavic state into schizophrenic situation. Consequently, these Europe's mixed political messages -most observes would agree- directly accelerated inner confrontations of the Yugoslav peoples. Soon after, Atlantic-Central Europe axis contained the western Balkans, letting the slaughter-house to last essentially unchecked for years. ${ }^{25}$ At the same time, it busily mobilized all resources needed to extend its own strategic depth eastwards (later formalized by the so-called enlargements of 1995, of 2004, of 2007 and finally of 2013). This is the only answer how can genocide and the EU enlargement go hand in hand at the same time on such a small continent.

As said, the latest loss of Russophone Europe in its geopolitical and ideological confrontation with the West meant colossal changes in Eastern Europe. We may take a look into geopolitical surrounding of at thetime largest eastern European state, Poland, as an illustration of how dramatic was it. ${ }^{26}$ All three land neigh-

25 The brief but bloody 1989 televised episode of a witch-hunt, followed by the hasty extrajudicial and savage killing of Romanian president and his wife Ceausescu, shocked the world - but not for long. The first ever fully televised war with its highly disturbing pictures of genocidal Armageddon came by early 1990s. It remained on TV sets for years all over Europe, especially to its East. Although the Atlantic-Central Europe axis kept repeating we do not know who is shooting whom in this powder keg and it is too early to judge, this -seemingly indecisive, wait-and-see, attitude- was in fact an undeniably clear message to everyone in Eastern Europe: No III way will be permitted. East was simply expected to bandwagon - to passively comply, not to actively engage itself.

26 Ethnically, linguistically and religiously one of the most homogenous countries of Europe, Poland in its post-communist concepts reinvigorates the faith (as being, past the days of Tadeusz Mazowiecki, massively de-Slavicized). No wonder as the Polish-born Karol Józef Wojtyła served the Roman Curia as Pontifex Maximus from 1978, to be replaced by the German-born Joseph Ratzinger in 2005. Prizing Roman-Catholicism over ethnicity, even harshly denouncing any Slavic sentiment as a dangerous roter russischer Panslawismus, 'fortress' Poland effectively isolates itself on a long-run as none of its neighbors is Catholic. To the contrary, the four fifths of its land-borders are shared with other Slavic states. To externally mobilize, the elites (in any East- 


\section{Bajrektarevic A.}

bors of Poland; Eastern Germany (as the only country to join the EU without any accession procedure, but by pure act of Anschluss), Czechoslovakia and the Soviet Union have disappeared overnight. At present, Polish border countries are a two-decade-old novelty on the European political map. Further on, if we wish to compare the number of dissolutions of states worldwide over the last 50 years, the Old continent suffered as many as all other continents combined: American continent - none, Asia - one (Indonesia/ East Timor), Africa - two (Sudan/South Sudan and Ethiopia/Eritrea), and Europe - three.

Interestingly, each and every dissolution in Europe was primarily related to Slavs (Slavic peo-ples) living in multiethnic and multi-linguistic (not in the Atlantic Europe's conscripted pure single-nation) state. Further on, all three - meaning, every second dissolution in the world - were situated exclusively and only in Eastern Europe. That region has witnessed a total dissolution of Czechoslovakia (western Slavs) and Yugoslavia (southern Slavs, in 3 waves), while one state disappeared from Eastern Europe (DDR) as to strengthen and enlarge the front of Central Europe (Western Germany). Finally, countless centripetal turbulences severely affected Eastern Europe following the dissolution of the SU (eastern Slavs) on its frontiers.

Irredentism in the UK, Spain, Belgium, France and Italy, or Denmark (over Faroe Islands and Greenland) is far elder, stronger and deeper. However, the dissolutions in Eastern Europe took place irreversibly and overnight, while Atlantic Europe still remained intact, with Central Europe even enlarging territorially and expanding economically.

As early as in XVI century, the Easter European thought - in the person of famous Sarajevan, Bosnian Machiavelli, Kafija Pruščak - is spelling a universal and far reaching wisdom that progress is both the focus of a vision and attainable reality for all. ${ }^{27}$ If this futuristic assertion is still accurate, than the progress itself is unthinkable without social cohesion. That would, consequently, necessitate shared interest which only comes with thorough debates affecting all segments of society (or at least its major interest groups). Is today's Eastern Europe a clas-sic case of indirect rule? Is it a deep imperial periphery of nominally independent na-

ern European state) would need an appealing intellectual case not a mare ethno-religious chauvinism.

27 Taken from Kafija Pruščak, H. (1596), Universal theory of the global governing wisdoms (Usul Al-hikam fi nizami-el-alem, org. Temelji mudrosti o uređenju svijeta). At the time, he was nicknamed in Western Europe as the Oriental Machiavelli. tive rulers, while in reality the true power holder resides outside, although is domestically suppor-ted by a dense web of NGOs, multinational corporations and locally handpicked 'elites'?

Accidentally or not, for the last 25 years, our reporting on Eastern Europe was rather a matter of faith than a reflection of the empirical reality. This 'rhetoric' was dominated by fragmented intellectual trends that are more cultural (e.g. poetry, paintings, film, etc.) than coherently economic and geopolitical in focus as they should be. How one defines a challenge largely determines the response - effectively points out Brzezinski. Hence, the arts will always elaborate on emotions and the science will look for the facts. If the front of Atlantic-Central Europe lately suffered (an economic) problem which has been diagnosed as a distributional and compositional, than who and when is holistically and scientifically to examine the EasternRusophone Europe and its burning geo-economic (distributional, compositional), socio-political/ideological (space-time in history) and geopolitical (logical and areal) problem? There is a lot of (pre-paid and postpaid) attention-diverting and velvet-silencing, but besides this cacophonic noise where is a serious research on that? If the equality of outcome (income) was a communist egalitarian dogma, is the belief in equality of opportunity a tangible reality offered to Eastern Europe or just a deceiving utopia sold to the conquered, plundered, ridiculed and cannibalized countries in transition?

By contrasting and comparing available HDI data (UN DP's Human Development Index) and all relevant WB, OECD, UNCTAD, ILO and WHO socio-economic and health indexes including the demographic trends of last two decades, we can easily spot a considerable economic and socio-human growth in Asia, in Latin America and elsewhere. The only trend of negative growth (including the suicide and functional illiteracy figures) comparable by its duration and severity to this of Eastern Europe, is situated in (the central-west, central to Horn/central-east portions of) sub-Saharan Africa. Euphemisms such as countries in transition or new Europe cannot hide a disconsolate fact that Eastern Europe has been treated as defeated belligerent, as spoils of war which the West won in its war against communist Russia. ${ }^{28}$

\footnotetext{
28 A sharp drop in LE (life expectancy) in Russia, from age 72 to 59 , is something faced only by nations at war. The evidence that Russia has suffered such a steep decline, unreversed ever since the collapse of the Soviet Union, is unprecedented in a peace-time history of any industrialized nation. Although not so alarming like in the post-Soviet Russia, the rest of post-Soviet republics and
} 


\section{Political science}

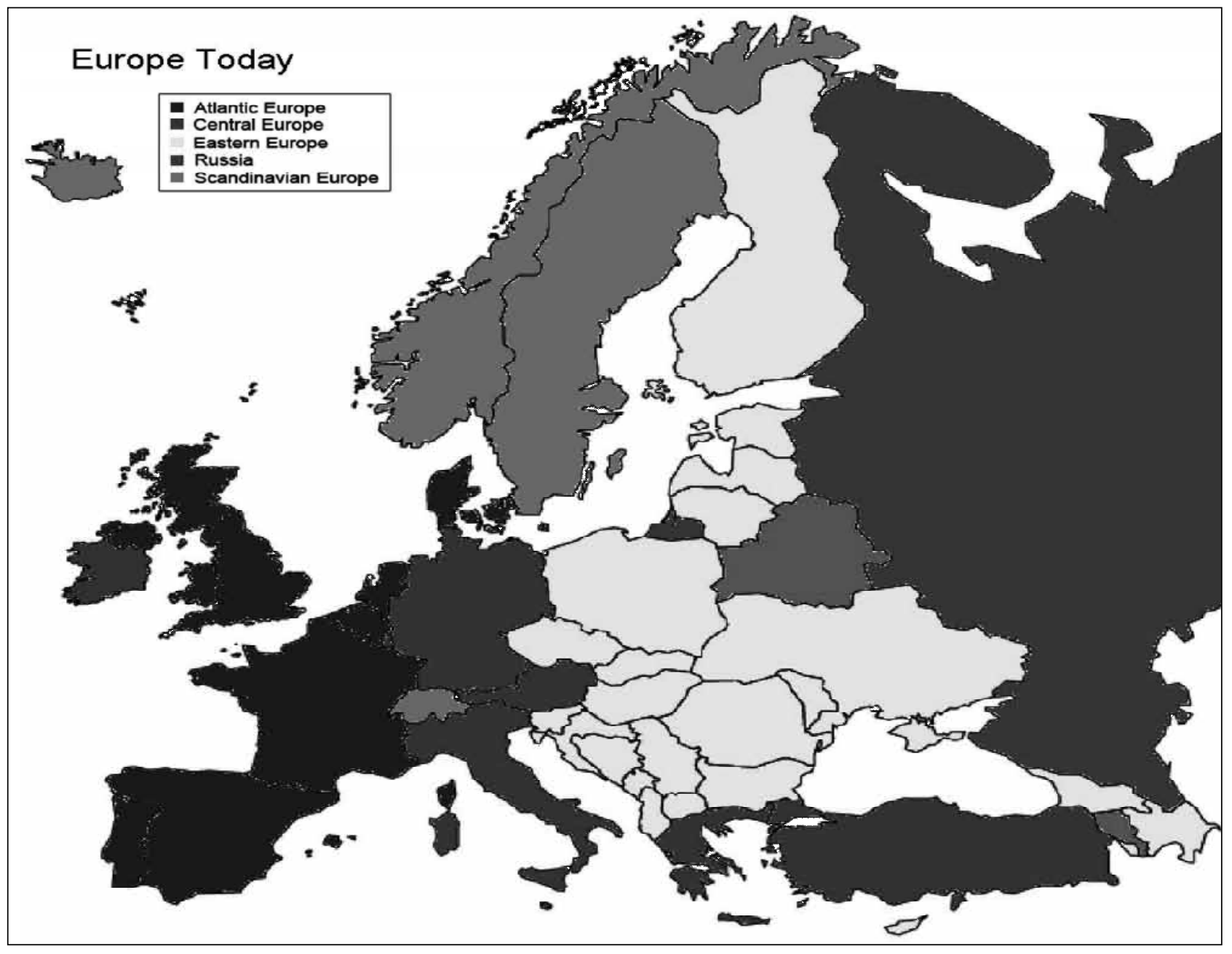

It concludes that (self-)fragmented, de-industrialized, rapidly aged and depopulated, (and de-Slavicized) Eastern Europe is probably the least influential region of the world - one of the very few underachievers. Obediently submissive and therefore, rigid in dynamic environment of the promising $21^{\text {st }}$ century, Eastern Europeans are among last remaining passive downloaders and slow-receivers on the otherwise blossoming stage of the world's creativity, politics and economy. ${ }^{29}$

Eastern Europe closely follow the same LA pattern - not to mention devastating birth rates, brain drain and other demographic data. E.g. the projected LA of the today's born Berliner is around 100 years, while of Muscovite is only 67 years. Simply, the East is unable to (re-)produce its own life (or, once conceived, to keep the best of it at home).

29 With some exceptions of Visegrád countries (such as Poland or Czech Republic, and lately Hungary) sporadically opposing a constant bandwagoning (but even that only in the domain of narrow EU fiscal or economic matters), Eastern Europe of today is unable to conceive and effectively promulgate a self-emancipat-
East does not exercise its political sovereignty (gone with the EU), its military sovereignty (gone with the NATO), its economic and monetary sovereignty (gone with the massive domestic de-industrialization 'preached' by the IMF, EBRD, EIB and eventually ECB),,

ing, balanced and multivector foreign policy. Fergusson goes as far as to claim for Eastern Europeans that: "they looked at Brussels (of NATO) the way former British colonies obeyed everything said and done in London."

30 "The entry criteria for Eastern European states was particularly costly: the so-called small and open economies, de-industrialized and over-indebted didn't have any chance to be equal partners. For most of them, FDI (Foreign Direct Investment) is the only economic solution, which turned them into colonies..."admitted even the Nobel laureate, economist Stiglitz in his The Price of Inequality. Moreover, the overly strong and rigid exchange rate of the domestic currencies in Eastern Europe is only good for foreign landers. It awards importers while disadvantages domestic manufacturing base and home exporters. This outdated anti-growth economic policy has been universally abandoned long ago, even by the LDC (the UN-listed Least developed coun- 


\section{Bajrektarevic A.}

and its financial sovereignty (gone by full penetration of German, Austrian and Swedish banks). ${ }^{31}$ Most of the Eastern European states do not control a single commercial bank on their territory. ${ }^{32}$ Additionally, this region does not effectively control its media space - media there (of too-often dubious orientation and ownership) is discouraging, disorienting and silencing any sense of national pride, influence over destiny direction and to it related calls for self-(re) assessment. East is sharply aged and depopulated -the worst of its kind ever - which in return will make any future prospect of a full and decisive generational interval simply impossible. $^{33}$

tries). No wonder that the GDP in the most of Eastern European states is below its pre-1990s levels.

31 According to findings of the Budapest Institute of Economics (Corvinus University of Budapest, Hungary), for the past two decades, the volume of Austrian banking sector has increased $370 \%$-all that in the country of a flat domestic economic and negative demographic growth. This covert occupation of south-eastern Europe by the foreign financial sector did not create new jobs or re-create any industrial base there. As we can conclude aftermath, it was only meant to dry-out the remaining liquid assets (and private savings) from the rapidly pauperized, defeated belligerent. In 1914, Austria controlled banks as well; in Croatia, Bosnia, Romania, Serbia, Hungary, southern Poland and western Ukraine. However, at that time, it also had a strict governing obligation as all of them were a part of the Monarchy. By having recognized the formal sovereignty to each of these entities, Austria today (like Sweden towards the three Baltic States in the northeast flank of Europe, and Germany in the central sector of Eastern Europe) has no governing obligations whatsoever. It can easily externally socialize (externalize) all its costs including banking risks, and individualize all profits (internalize), yielding it only for itself. Hence, the EU accession criteria, combined with a nominal independence of Eastern European entities (pacified by the pre-paid media and guided by the post-paid 'elites'), means that the economic and other assets are syphoned out, but the countries have to take a burden of the state maintenance solely on themselves.

32 Current labor relations in the most of Eastern Europe ( $\mathrm{Ru}-$ sophone Europe, too) resembles pictures of the 18th rather than of the 21st century's conditions, especially in the private sector of employment. It is all with a weak or even totally absent trade unionism, dismal labor rights and poor protection of other essential social rights. "We have stringent labor conditions to the unbearable maximum, so that the few self-styled 'top managers' can play golf more frequently and for a longer time... how can you possibly build any social cohesion when disproportionately many suffer for the dubious benefit of the asocial, predatory few..." confessed to me the Ambassador of one of the largest Eastern European countries who served as a mayor of his country's capital, before his ambassadorship in Vienna.

33 Some ten years ago, for the special OSCE forum for demographics, I warned: “...lasting political, social and economic changes including very important technological breakthroughs throughout our history - primarily occurred at generational in-
Honduras-ization of Eastern Europe is full and complete. ${ }^{34}$ If the post-WWII Soviet occupation of Eastern Europe was overt and brutal, this one is tacit but subversive and deeply corrosive. ${ }^{35}$

Interestingly, the physical conquest, usually referred to as the EU enlargement, was primarily the USled NATO one, and only then the EU enterprise. Simply, no eastern European country entered the EU before joining the NATO at first. It should not be forgotten

tervals. This was an engine of our evolution...Presently, with demographically collapsing East European societies (natality rates, generational and brain drain), the young cohort will never constitute more than a tiny minority - in the sea of aged, backwardlooking, psychologically defeatistic and biologically incapable, conservative status quo keepers. Hence, neither the generational change that brings fresh socio-political ideas, nor technological breakthrough -which usually comes along - will successfully ever take place in future of such demographics." (For a detailed demographic outlook and tentative recommendations/ conclusions, see: Bajrektarevic, A. (2005), Our Common Futures: EURO-MED Human Capital beyond 2020, Crans Montana Forum, Monaco, 2005, as well as Bajrektarevic, A. (2005), Green/Policy Paper Submitted to the closing plenary of the Ministerial (Chairmanship summarizing the recommendations and conclusions of the OSCE Ministerial Summit Prague 2005), OSCE Documents EEA 2005.)

34 Eastern Europe is Hondurized - this term refers to an operationalization of Monroe Doctrine in Central America, by which Washington allows its strategic neighborhood to choose their own domestic political and economic systems to an acceptable degree, while the US maintains its final (hemispheric) say over their external orientation. The so-called Brezhnev doctrine (of irreversibility of communist gains) postulated the Soviet (SuslovStalin) equivalent to Honduras-ization - Finlandization.

35 Eastern Europe, the (under-)world of dramatic aging which is additionally demographically knocked down by the massive generational and brain drain. Passed the dismantling of the communist order, these emerging economies, countries in transition of the new Europe contain reactionary forces (often glorifying the wrong side of history), predatory 'elites' and masses of disillusioned (in a life without respect and dignity, humiliated and ridiculed in the triviality of their lasting decline). Even if the new jobs are created or old kept, they are in fact smoke screens: Mostly a (foreign-loans financed) state-sponsored poverty programs where armies of the underemployed and misemployed cry out miserable wages in dead-end jobs. Former Slovakian cabinet minister laments in private: "Our 'liberated East' lives on foreign loans, or in the best case as the industrial suburbia of West Europe, having these few 'generously' franchised factories like Renault, VW or Hugo Boss. Actually, these are just automotive assembly lines and tailor shops - something formally done only in the III World countries. Apart from the Russian EnergiaSoyuz (space-program related) delivery system, what else do we have domestically created anywhere from Bratislava to Pacific? Is there any indigenous high-end technical product of past decades known? ... Our EU accession deals are worse than all Capitulation agreements combined that the Ottomans and Imperial China have ever signed in their history." 


\section{Political science}

that the NATO was and remains to be an instrument (institutionalized political justifier) of the US physical, military presence in Europe. Or, as Lord Ismay vocally defined it in 1949: 'to keep the Russians out, the Americans in, and the Germans down'. The fact that the US remained in Western Germany, and that the Soviet Army pulled out from Eastern Germany did not mean 'democratization' or 'transition'. It was a direct military defeat of the Gorbachev Russia in the duel over the core sectors of Central and Eastern Europe. As direct spoils of war, DDR disappeared from the political map of Europe being absorbed by Western Germany, while the American Army still resides in unified Germany. In fact, more than half of the US 75 major overseas military bases are situated in Europe. Up to this day, Germany hosts 25 of them.

Admittedly, by the early 1990s, the 'security hole'Eastern Europe, has been approached in multifold fashion: Besides the (pre-Maastricht EC and post-Maastricht) EU and NATO, there was the Council of Europe, the CSCE (after the 1993 Budapest summit, OSCE), the EBRD and EIB. All of them were sending the political, economic, human dimension, commercial signals, assistance and expertise. ${ }^{36}$ These moves were making both sides very nervous; Russia becoming assertive (on its former peripheries) and Eastern Europe defiantly dismissive. ${ }^{37}$

36 Through the EBRD-EIB conditionalities and EU accession criteria, Eastern Europe was dictated to practically dismantle its essential industrial and service base. This dictatum upon defeated belligerent - euphemistically called countries in transition or new Europe - was followed by loans and assets received from the EU Accession and Structural funds. It was 'sold' to the East as award and as such presented to the deceived population. (However, it was rather to tranquilize the population at large and to pacify their local scenes, not at all aimed to modernize, re-industrialize or diversify economy, or to make production and service sector more efficient or competitive. Consequently, it was merely to subsidize the deteriorating purchasing power of the East - to make the peoples there accustomed to and encouraged for the foreign goods and services.) Thus, the funds were predominantly consumed for the western commodities. Ergo, Atlantic and Central Europe extended themselves geographically, while economically they skillfully managed to subsidize their own industrial base. To this very end, Eastern Europe's elites readily took loans, while -in return- laying down sovereignty in issuing the guaranties. By doing so, they indebted their own states beyond bearing, and hence, they finally eliminated their own countries as any current or future economic competitor or politico-military challenger.

37 Since the end of WWII, there was no other external military interventions but to the Europe's East. To be accurate, in its long history (earlier and nearly double longer than of the Warsaw pact), the only two interventions of NATO ever conducted in Europe were both taking place solely on Eastern European soil. While the two Russian (covert) interventions aimed at its strategic neighborhood (former Soviet republics, heavily inhab-
Until this very day, each of them is portraying the NATO enterprise as the central security consideration: One as a must-go, and another as a no-go. ${ }^{38}$

No wonder that the absolute pivot of Eastern Europe - Ukraine, is a grand hostage of that very dilemma: Between the eastern pan-Slavic hegemony and western 'imperialism of free market'. ${ }^{39}$ For Ukraine, Russia is a geographic, socio-historic, cultural and linguistic reality. These days, this reality is far less reflected upon than the seducing, but distant Euro-Atlantic club. Ukraine for

ited by ethnic Russian; Abkhazia-South Ossetia and Crimea-East Ukraine) and were (unsuccessfully) justified as the encirclement preemption, the US-led NATO intervened overtly. In both NATO cases (Bosnia and Serbia-Kosovo), it was well beyond any membership territory, and short of any UN-endorsed mandate, meaning without a real international legitimacy. "Humanitarian intervention in Kosovo was never exactly what it appeared... It was a use of imperial power to support a self-determination claim by a national minority" - wrote Michael Ignatieff about the 1990s Balkans events, as fresh and accurate as if reporting was from Sevastopol in spring 2014.

38 It is anticipated that Iran (and Syria) on the Russian southwest flank serve as a pivotal security buffer. Indeed, Teheran is in constant need of a diplomatic cover from Moscow - as it internationally seeks, at least, a turn-key technology legalization for itself. In return, Iran refrains from its own Islamic projection on and it shields the Caucasus and Central Asia - considered by Russians as their strategic backyard - from the assertive Wahhabism. On the other hand, boldness of Iran endorses a perfect pretext for a reinforced missile shield. This - interestingly enough - rather encircles Russia then it deters Iran, as the recent architecting of the Missile shield predominantly to Eastern Europe (from the Baltics, Poland, Czech Republic and Romania) has showed. There are exceptionally few reinforced Patriot missile batteries (of adequate quantities and configurations) stationed e.g. in Turkeythe only NATO member of a close proximity, capable to engage Syria or Iran. Hence, while such a missile hype does not deter Iran (does not democratize Turkey, does not bring stability to Iraq, nor the regime change in Syria), it still achieves a lot. It seriously compromises the 1990 CFE Treaty, since the US unilaterally withdrew from the 30 -years-in-place ABM treaty in 2002, and poses a challenge to the OSCE guarded politico-military/CSBM cooperation among the Organization's 56 member states.

39 It is further burdened by the imperialism in a hurry - an inflammable mix of the Lithuanian-Polish past traumas and German 'manifest destiny' of being historically yet again ill-fated; impatient for quick results - simply, unable to capitalize on its previous successes. One of my German students recently very vividly ironized: "The irony of unintended consequence is that the intense relationship between Über-mutti (Chancellor Merkel) and boxman at large Klitschko is interpreted by Moscow as asexual, but not as apolitical." To say, overly cosmopolitan interest for a faith of foreigners living in Germany for someone who infamously said: "multiculturalism is dead in Europe..." (Sarkozy, Cameron and Merkel openly and repeatedly viewed and diagnosed 'death of multiculturalism', as if the cluster of AtlanticCentral Europe's national-states lived a long, cordial and credible history of multiculturalism on its soil. 


\section{Bajrektarevic A.}

Russia is more than a lame western-flank' geopolitical pivot. For Moscow, Kiev is an emotional place - an indispensable bond of historio-civilizational attachment - something that makes and sustains Russia both Christian and European. Putin clearly redlined it: Sudden annexation of Crimea was an unpleasant and humiliating surprise that will bring a lot of foreign policy hangover for both the NATO and EU. Thus drifting chopped off and away, Ukraine itself is a prisoner of this domesticated security drama. This false dilemma so tragically imploded within this blue state, of a 50:50 polarized population, over the question where the country belongs - in space, time and side of history. Conclusively, Eastern Europe is further twisting, while gradually combusted between Ukrainization and Pakistanization. ${ }^{40}$

\section{Least to the East and Nest of the West}

The EU has secured itself on the southeastern flank, too. In the course of last few centuries, the Balkans was either influenced or controlled by Russia on the east (also by the Ottomans), Turkey on the south and center, Austria on the north and west, with the pockets of Anglo-French influence, too (Greece, Serbia, Albania). This reads that ever since the late XVII c. (precisely, from 1686 when Russia joined the Holy League, and past the subsequent 1699 Treaty of Karlovci), the peripheries kept center of the Balkans soft, as their own playground. The only (pre-modern and modern) period when the center was strong enough to prevail, marks the time of the Balkans' Bismarck: Tito of Yugoslavia.

Presently, the Eastern Balkans (Romania and Bulgaria) is cutoff from any Russian influence by being hastily admitted to the Union (2007). Turkey is contained by Greece (1980) and Cyprus (2004), and is waiting on the EU doorstep for decades without any clear prospect to join. ${ }^{41}$ All that, as if it follows

40 Ukrainization could be attributed to eastern and western Slavs- who are fighting distinctions without significant difference. Pakistanization itself should describe the southern Slavs' scenery: In lieu of truth and reconciliation, guilt is offered as a control mechanism, following the period of an unchecked escalation, ranging from a hysteria-of-a-small-difference to a crime-ofotherness purge.

${ }^{41}$ Why is the biggest and richest city of Europe (still) outside the Union? Does it illustrate a Huntingtonian fact that the EU is not as multi-religious multilateral system as its younger (twin) brother - ASEAN, but only a nest for the western Christian Ummah? True, but not completely. The last spot of Europe with both economic and demographic growth is Turkey. Just one more European country also has a steady economic growth - Russia. Another commonality for them is that both are outside the system which portrays itself as a truly Europo-cosmopolitan and pan- the old rational of the 1814 Vienna Congress as well as the Bismarck's dictatum to Andrássy at the 1878 Congress of Berlin. Reinvigorating these geo-economic and strategic imperatives, Austria does not hesitate to add and shed emotional charge: it is nearly neuralgic on the Turkish EU accession, Russian presence or inner Slavic strength. In an attempt to control the core sectors of the Balkans, Austria jealously keeps the highest post in the Office of High Representative for Bosnia in its hands. ${ }^{42}$ At the same time, it is the main protégé of Croatia's bid for the EU membership (2013). De-industrialized, over-indebted and increasingly de-Slavicized, Croatia - for that matter of course, further fortifies the Austro-influence deeper in the Balkan proper. ${ }^{43}$

The rest of the Western Balkans is still finishing the dissolution of Yugoslavia, by forming the ever smaller, incapacitated mini nation-states. (The prevailing political culture of the Western Balkans is provincial, anti-

European. There was another time when Europe claimed to have a comprehensive multilateral setting, while keeping two pivotal powers outside the system-interwar period. No wonder that the League of Nations did not prevent but, on contrary, only accelerated the pre-WWII events with its 'system error', (in)action and lack of outreach.

42 Colloquially known as the Colonial Office, OHR (Office of the High Representative) is the (US military base induced, the 19th century Congress look alike) 'internationally' set body with the supreme (legislative) prerogatives and highest executive (political) powers in the country. This non-UN-, non-OSCE-, and non-EU mandated office is increasingly criticized for its shadowy influence and opaque decision-making. Since its inauguration in 1995, the post of the chief OHR executive - High Representative (nicknamed as Colonial Governor), is dominated by Atlantic-Central Europe -6 out of 7 individuals. Although Austria itself is regularly criticized for its dismal score on protection of minorities, it managed - like no other state to get the top OHR post twice, and to stay in that office for already 9 out of 19 years. Moreover, as the first and only country ever under the EU sanctions (for inviting its far-right political party to the coalition government in 2000), Austria was strong-ly condemned by all EU member states, but not in Bosnia, where it continued to keep the post of the High Representative.

43 In his well-publicized Sarajevo speech, Turkish Foreign Minister Davutoglu returned the usual EU rhetorics back to the European front-yard: “...I have to say that my country is disappointed that an important religious symbol, that of a minaret, has been subjected to a referendum in Switzerland. It is a mistake to put a fundamental religious right to a popular vote and I hope that this mistake will be rectified. The spread of human rights and fundamental freedoms may not have been possible, had countries chosen to put specific freedoms to referenda. It might be useful to recall that the Franciscan Catholic Monastery in Fojnica, some 35 miles from here- Sarajevo, holds the original copy of an edict issued by the Ottoman Sultan on 28 May 1463. This edict protects the religious rights of Bosnian Christians and the sanctity of their churches. It is one of the oldest documents on religious freedom in Europe ever." (BiH MVP Archives, 14 DEC 2009) 


\section{Political science}

intellectual, xenophobic, irresponsible anti-politics). Less than a decade after President Tito's death, the tectonic changes in the Eastern bloc have caused the dramatic change of geopolitical position of Yugoslavia and the NAM. The external players and local élites, whom they chose to boost and cooperate with, had silently agreed that for the amortization of revived Anglo-French, Germanophone, Russian and Turkish (traditional), and the US (non-traditional) projections on the region, the Southern Slavs should (de-industrialize, de-Slavicize, and) live in far more than two states. In the absence of compromise among the major external geopolitical projectors, the region still undergoes the fragmentational erosion, being kept (like once upon a time Germany) as a soft center for strong peripheral pressures. ${ }^{44}$ Bosnia is the best example of such an external intrusion, and of the powers that purposely set a dysfunctional government. ${ }^{45}$ Although assertive, none of the Four + the US wants to prevail in this core sector of the Balkans (and solely take a burden), but wish to keep its presence strong enough as to observe and deter others.

Nevertheless, ever since the Antique Roman times, the Southern Slavs territories (even all of the Balkans) have always existed within the larger multinational entities (be it Byzantium, Hungary, the Ottomans, the Habsburg Empire or Yugoslavia) - hardly ever in more than two states. Accommodation to a life in the numerous nano nation-state-alikes is a historical novelty, therefore only a transitory stage of the Western Balkans. ${ }^{46}$ The lasting solution will only ap-

44 How deep is the rabbit hole... Republic of Macedonia is a good demonstration case for it. No other European country was forced to abandon its own constitutional name and seek the international recognition under the strange name of a saturated country that does not exist anymore for over 20 years - Former Yugoslav Federal Republic of Macedonia.

45 By far the largest EU Delegation ever run is the Mission in Bosnia (Delegation of the EU to $\mathrm{BiH}$ ). As the Mission's staff kept increasing over the last two decades, so did the distance of Bosnia from any viable prospect of joining the Union. Many around are bitterly joking if the Mission's true mandate is - in fact - to hinder, and not to assist the EU integration. According to the UN and ICTY, Bosnia has suffered genocide on its territory - the worst atrocities on European soil since the end of WWII. Judging the speed of admission process offered to Bosnia, seems that the EU does not like its victims. Sarajevo 20 years after is a perfect litmus paper - an EU barometer, for the ethical deficit of the Union and its members!

46 Bosnia as a habitual mix of cultures, ethnicities and religions has a historical legacy and strong quality of integration, a cohesive spill-over potential for the region. Therefore, instead of conceptual politics after the war, the territorial anti-politics (with the confrontational political culture) was at first externally imposed by the so- pear with the return to a historical legacy -life in a larger, multinational entity.

In his luminary work 'The New Asian Hemisphere', Mahbubani accurately concludes that Gorbachev - not understanding the real success of Western strength and power, handed over the Soviet empire and got nothing in return. ${ }^{47}$ Is our history directional or conceivable, dialectic or cyclical? The Soviet Union was far more of a classic continental military empire (overtly brutal; rigid, anti-individual, omnipresent, secretive), while the US was more a finan-cial empire (covertly brutal; hierarchical, yet asocial, exploitive, pervasive, polarizing). Bear of permafrost vs. fish of the warm seas. Athens vs. Sparta. Phoenicia vs. Rome. Thus, Soviets went bankrupt by mid 1980s. So did the Americans (the 'white man burden' fractured them already by the Vietnam war, with the Nixon shock only officializing it), but the United States managed its financial capital (or an illusion of it) insofar as to be(come) a debtor empire through the Wall Street guaranties. ${ }^{48}$ Sputnik titanium

called Dayton Peace Accord, and further on strongly encouraged and supported in everyday practice for nearly two decades. It is clear that any conceptual, therefore inclusive politics, would sooner or later end up in a reconciliatory, integrative approach. Perpetuating the anti-politics in Bosnia aims at keeping the former Yugoslav (political, cultural, economic and territorial) space separated, antagonized - fragmented into little xenophobic and inward-looking quasi nation-states. Moreover, as the only surviving (last) state of the multiethnic constituency anywhere from Adriatic to Pacific, Bosnia has to remain purposely dysfunctional. Slavs elsewhere have to be painfully reminded that a single-ethnos based, nano-tosmall sized nation-state is the best option for them.

47 Or, by the words of the senior UN diplomat who, contemplating with me over the question whether a middle-power foreign policy is adequate for a great power, recently told me in Geneva: "The difference between Russia and the Soviet Union is that the Federation desperately looks around for respect, but leaves the world responsibilities solely to the US. As known, admiration and respect is earned not given for free." Clearly, the post-Soviet Russia avoids any strategic global competition with the US, but feels rather insulted with the current strategic global partnership - as both the US and China treat Moscow as a junior partner. Is it possible to (re-)gain a universal respect without any ideological appeal? That could be debated, but one thing is certain, even the mid-size powers such as Brazil, Indonesia or Turkey have moved on from a bandwagoning, reactive and slow to a proactive, accurate and extensive foreign policy.

48 How was a debtor empire born? One of the biggest (nearly schizophrenic) dilemmas of liberalism, ever since David Hume and Adam Smith, was an insight into reality; whether the world is essentially Hobbesian or Kantian. The state will rob you, but in absence of it, the pauperized masses will mob you. The invisible hand of Smith's followers have found the satisfactory answer - sovereign debt: relatively strong government of the state (heavily) indebted (firstly to local merchants, than to foreigners). With such a mixed blessing no empire can easily demonetize its legitimacy. 


\section{Bajrektarevic A.}

vs. gold mine of printed paper. Nothing epitomizes this better than the words of the longest serving US Federal Reserve's boss, Greenspan, who famously said to then French President Chirac: "Indeed, dollar is our currency, but your problem". Hegemony vs. hegemoney.

This very nature of power explains why the Americans have missed to take the mankind into completely other direction, towards the non-confrontational, decarbonized, de-monetized/de- financialized and depsychologized, the self-realizing humankind. They had such a chance when, past the Gorbachev's unconditional surrender of the Soviet bloc, the US - unconstrained as a 'lonely superpower' - solely dictated terms of reference. ${ }^{49}$ Sadly enough, that was not the first missed opportunity for the US. The very epilogue of the WWII meant a full security guaranty for the US: Geo-economically $-52 \%$ of anything manufactured in the world was carrying a label Made in USA, and geostrategically - the US had uninterruptedly enjoyed nearly a decade of the 'nuclear monopoly'. Up to this very day, the US scores the biggest number of $\mathrm{N}$-tests conducted, the largest stockpile of nuclear weaponry, and it represents the only power ever deploying this 'ultimate weapon' on other nation. To complete the irony, Americans enjoy geographic advantage like no other empire ever. Save the US, as Ikenberry vividly notes: "every major power in the world lives in a crowded geopolitical neighborhood where shifts in power routinely provoke counterbalancing..." ${ }^{50}$ The US neighbors are oceans.

Indeed, no successful empire does rely merely on coercion, be it abroad or at home. However, unable to escape its inner logics and deeply-rooted appeal of confrontational nostalgia, the prevailing archrival is only a winner, rarely a game-changer. ${ }^{51}$ So, to the above asked

49 One of the biggest ideological victories of the US is the fact that only two decades years after the Soviet collapse, Russia today has an economy, dominated by oil-rich class of billionaires, whose assets are $20 \%$ of country's GDP -by far the largest share held by the ultrarich in any major economy. The second largest ideological victory for the US is reported by the New York Times that the outgoing leader of the country that officially rests on ideology of oppressed working class has allegedly accumulated family wealth of 1,7 billion in less than a decade of his rule. Some in the US are not that happy about it, and are wondering - like Fukuyama in his luminary essay - "where is a counter-narrative?" To ease the pain for all balance-seekers: Even if the ideological triumph of the US might be a clear cut, geopolitically it remains undecided. While Russians were absorbing the shock of loss of their historical empire, the 'lonely superpower' didn't know what to do with its colossal gain.

$50 \quad$ Ikenberry, G.J. (2014), The Illusion of Geopolitics, Foreign Affairs Magazine 93(3) 2014

51 There are many who would claim that the West was unable to capitalize on the collapse of the Soviet Union, and that the question whether our history is dialectic or cyclical, the current Ukrainian events are like a bad-taste déjà vu.

'End of the Cold War' - such a buzz word, of a diametrically different meaning. East would interpret it as the final end of confrontation, while the Westerners have no such an illusion. To them it is the end of war, which only came after the unconditional surrender of East. Another powerful evidence to support our claim: Just 20 years ago, distance between Moscow and NATO troops stationed in Central Europe (e.g. Berlin) was over $1.600 \mathrm{~km}$. Today, it is only $120 \mathrm{~km}$ from St. Petersburg. ${ }^{52}$ Realities have dramatically changed for the Atlantic-Central Europe and for Russia, while for Eastern Europe much remains the same - East still serves others as a strategic depth. ${ }^{53}$

In short, Atlantic Europe is a political powerhouse, with two of 3 European nuclear powers and 2 out of five permanent members of the UN Security Council, P-5. Central Europe is an economic powerhouse, Russophone Europe is an energy power-house, Scandinavian Europe is all of that a bit, and Eastern Europe is none of it. ${ }^{54}$

real winner of the superpowers' playoff is actually the third. It is not only that Asia is resurfacing very self-confident. Deeper and structural, the issue is more subversive as well: One of the most remarkable achievements in the world history of capita-lism is happening under the leadership of the largest Communist party on this planet. The very epilogue of lasting ideological confrontation between Byzantium and (Sassanid) Persia and their colossal geopolitical overextension, was an appearance of the third power center on geopolitical and ideological terrain, gradually prevailing from the 7 th century onwards.

52 Despite the (formal) end of the Cold War, and contrary to all what we celebrate as a technological progress, our Gini coefficients' distances are far larger than they were two decades ago. Additionally, as the EU was getting closer to Eastern and Russophone Europe, the socio-economic inequalities and politicocultural exclusions there were growing wider.

53 Before too long, Washington will have to decide: either containment or accommodation - a viable truce with Moscow or unconditional backing of Russia's closest neighbours. If Putin finally abandons the non-confrontational course, and regularizes the play on a confrontational nostalgia card, the US-led West might award Moscow by returning Baltics, some central-southern portions of Eastern Europe, along with Central Asia and Caucasus to Russian sphere of influence. If the history of Russo-American confrontations is deep, wide and long, their ability to broker a deal is remarkably extensive, too. Or, as prof. W.R. Mead elaborates: "...In deciding how hard to press Russia over Ukraine, the While House cannot avoid calculating the impact on Russia's stance on the Syrian war or Iran's nuclear program." (Mead, W.R. (2014), The Return of Geopolitics, Foreign Affairs Magazine 93(3) 2014)

54 Does anyone still remember 'heroic' labor union Solidarność from the Gdańsk shipyards? Well, today there are no more unionists, their leader Lech Wałęsa is forgotten, as there are no ship- 


\section{Political science}

\section{From WWI to www. $9 / 11$ or $11 / 9$ ?}

For most of our history both progress as well as its (horizontal) transmission was extremely slow and tedious a process. Well to the classic period of Alexander the Macedonian and his glorious Alexandrian library, the speed of our transmissions -however moderate- was still always surpassing cycles of our breakthroughs. When the breakthroughs finally turned to be faster than the speed of their transmissions - that was a point of our departure. Simply, our civilizations started to significantly differentiate from each other in their respective techno-agrarian, politico-military, ethno-religious, ideological and economic set-ups. In the eve of grand discoveries, that very event transformed wars and famine from the low-impact and local into the bigger and colossal. Faster cycles of technological breakthroughs, patents and discoveries than their own transmission, primarily occurred on the Old continent. That event marked a birth of mighty European empires and their (liberal) schools of applied biologism, racism, genocide, organized plunders, ethno-social engineering and eugenics, and similar forms of ideological justifiers. For the past few centuries, we lived fear but dreamt hope - all for the sake of modern times. From WWI to www. Is this modernity of internet age, with all the suddenly reviled breakthroughs and their instant transmission, now harboring us in a bay of fairness, harmony and overall reconciliation? ${ }^{55}$

yards ever since Poland (eager, but without careful preparations have) opened its EU accession talks... The similar termination of all public subsidies is stipulated in chapter 8 (Competition Policy) of the accession treaty admitting Croatia to the EU, and the European Commission has been closely monitoring the implementation of the 'restructuring' program for the Croatian shipyards. This ongoing shipyards demise will complete Croatia's de-industrialization (adding to the already record high unemployment of some $25 \%$ in the coastal areas). All over the globe, states assist shipbuilding as it is a formidable job provider: In Italy, the Fincantieri shipyards are entirely in public hands; in France, the state is still a minority shareholder in the biggest yards such as STX-Chantiers de l'Atlantique. Even in South Korea, the world champion in naval construction, the state subsidizes shipbuilding. Seems that all what is globally acceptable is forbidden in Eastern Europe; all the way from Poland to Croatia, in the name of European integration.

55 At this point, let me allow myself a little story in bracket. It is not to romanticise the past but to note on an erosion of one very important governmental post, which is a key for daily execution of international relations... By my free account, in 1815 at the time of Vienna Congress, there are not more than 50 ambassadors worldwide. By the Berlin Congress, their number is still well below 100. Each and every one of them is an exceptional individual of the high moral grounds, of a deep passion affection and loyalty, of an excellent professional standing. Well-
100 years after the outbreak of the WWI on $28^{\text {th }}$ June 2014, young generations of Europeans are being taught in schools about a singularity of an entity called the EU. However, as soon as serious external or inner security challenges emerge, the compounding parts of the true, historic Europe are resurfacing again. Formerly in Iraq (with the exception of France) and now with Libya, Mali, Syria and Ukraine: Central Europe is hesitant to act, Atlantic Europe is eager, Scandinavian Europe is absent, and while Eastern Europe is bandwagoning, Russophone Europe is opposing. The 1986 Reagan-led Anglo-American bombing of Libya was a one-time, head-hunting punitive action. This time, both Libya and Syria (Iraq, Mali, Ukraine, too) have been given a different attachment: The considerable presence of China in Africa; successful pipeline deals between Russia and Germany (which, while circumventing Eastern Europe, will deprive it from any transit-related bargaining premium, and will tacitly pose an effective joint Russo-German pressure on the Baltic states, Poland and Ukraine), ${ }^{56}$ and finally relative decline of the

mannered and well-informed, erudites, thinkers of paramount analytical insights, charismatic charming and highly intelligent, they represented intellectual crème de la crème of that time societies. By the 1945 San Francisco Conference, the world already counts several hundreds of active ambassadors. At present, there are some 25-30,000 individuals with this title (20-25,000 active national, and some $5-8,000$ retired national, as well as up to 1,000 paradiplomats of ambassadorial ranks serving IOs). Sadly enough, in more than a few cases, this post is obtained today by persons who are simply career opportunists, without sufficient professional or moral merits to hold ambassadorial position (individuals who just climbed their careers by being yes-men, no-action-no-mistake-stance grey apparatchiks, disloyal bed mannered and ill-informed but well webbed-up in either nepotistic or crony networks, political removals, rich individuals who bought the post much like the car is purchased). In this gradual but total erosion of ambassadorship, something still remains firm and stabile: privileges, immunities and of course a paycheque /Source on figures: author's free account./

56 In late spring 2011 Chancellor Merkel has surprisingly but repeatedly and firmly promised to her fellow Germans the closing of all national nuclear plants. Mixing it with the growth and stability move, many applauded to this heated political rhetoric, as a long-waited and badly needed plan for the High/Green Tech renewal of the EU. Adding a flavor of emotional charge to it, most analysts have interpreted the Chancellor's bold word of promise with the safety concerns related to that time brewing Japanese Fukoshima drama, as if Germany shared Japan's geography, reactor technology and seismic activity. However, the majority of commentators remained silent on the timing which was well coinciding with the successful completion of the first phase of the so-called North Stream. It was the first of several planned, long pipelines that delivers hydrocarbons from Russia directly to Germany via the North Sea seabed. This arching pipeline eliminates any transit bargaining premium from the Eastern Europeans and 


\section{Bajrektarevic A.}

US and re-calibration of their European commitments. All of this combined, must have triggered alarm bells across Atlantic Europe. ${ }^{57}$

This is to understand that although seemingly unified, Europe is essentially composed of several segments, each of them with its own dynamics, legacies and its own political culture (considerations, priorities and anxieties): Atlantic and Central Europe confident and secure on the one end, and (the EU and non-EU) Eastern Europe as well as Russia on the other end, insecure and neuralgic, therefore, in a permanent quest for additional security guaranties.

"America did not change on September 11. It only became more itself" - Robert Kagan famously claimed. ${ }^{58}$ Paraphrasing it, we may say: From 9/11 $\left(09^{\text {th }}\right.$ November 1989 in Berlin) and shortly after, followed by the genocidal wars all over Yugoslavia, up to the Euro, MENA or ongoing Ukrainian crisis, Europe didn't change. It only became more itself - a conglomerate of five different Europes.

\section{Post Scriptum}

How can we observe and interpret (the distance between) success and failure from a historical perspective? This question remains a difficult one to (satisfy all with a single) answer... The immediate force behind the rapid and successful European overseas projection was actually the two elements combined: Europe's technological (economic) and demographic expansion (from early $16^{\text {th }}$ century on). However, West/Europe was not - frankly speaking - winning over the rest of this planet by the superiority of its views and ideas, by purity of its virtues or by clarity of its religious thoughts and practices. For a small and rather insecure civilization, it was just the superiority and efficiency in applying the ratio-

poses in effect a joint Russo-German pressure on the Baltic states, Poland, Ukraine, and even as far as Azerbaijan and Georgia.

57 In response to the MENA crisis, Europe failed to keep up a broad agenda and all-participatory basis with its strategic neighborhood, although having institutions, interest and credibility to do so. Europe compromised its own perspectives and discredited its own transformative powers' principle by undermining the indigenous and authentic institutional framework: Barcelona Process (EU), the Euro-Med (OSCE). The only direct involvement was a military engagement via the Atlantic Europe-led coalition of the willing (Libya, Mali, Syria). The consequences are striking: The sort of Islam that the EU supported (and the means deployed to do so) in the Middle East yesterday, is the sort of Islam (and the means it uses) that Europe gets today. No wonder that Islam in Turkey (or in Kirgizstan and in Indonesia) is broad, liberal and tolerant while the one of the Northern Europe is dismissive, narrow and assertive.

58 Kagan, R. (2004) Of Paradise and Power, Vintage Books (page 85).

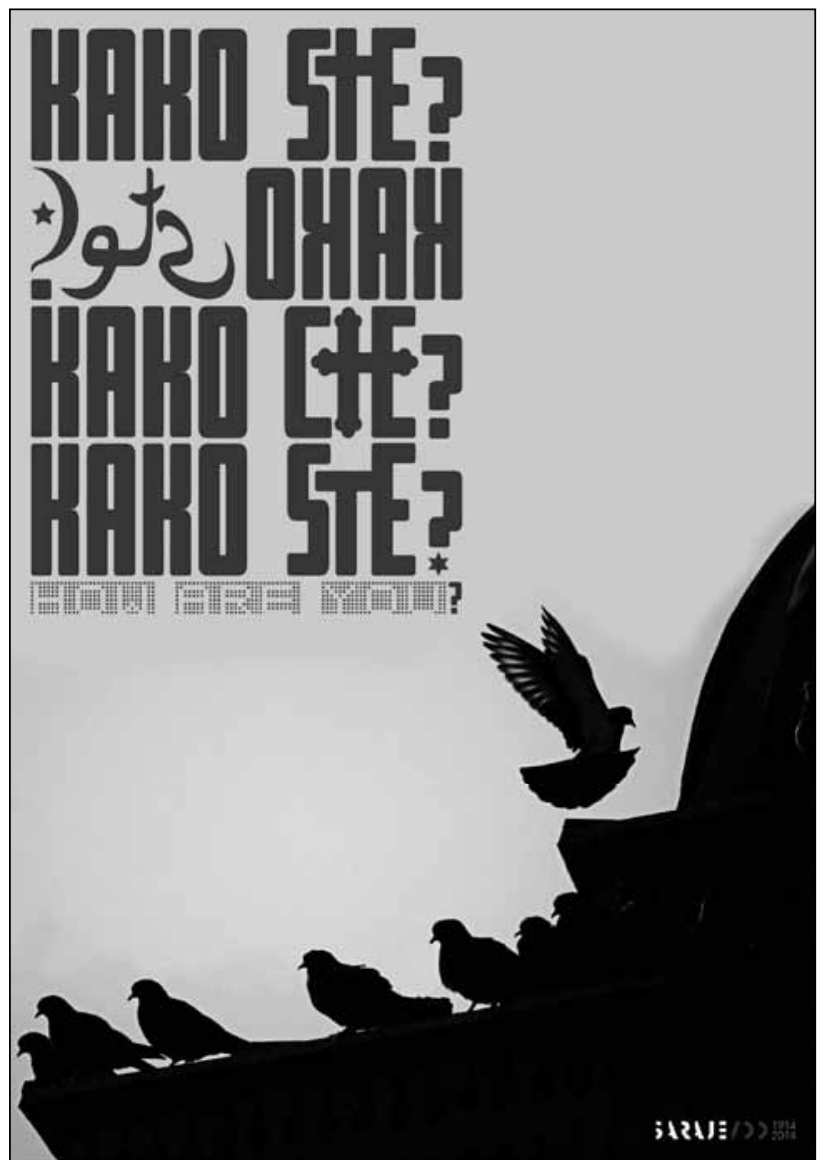

nalized violence and organized (legitimized) coercion that Europe successfully projected. The $21^{\text {st }}$ century Europeans often forget this 'inconvenient truth', while the non-Europeans usually never do.

The large, self-maintainable, self-assured and secure civilizations (e.g. situated on the Asian landmass) were traditionally less militant and confrontational (or the nation-state 'exclusive'), but more esoteric and generous, inclusive, attentive and flexible. The smaller, insecure civilizations (e.g. situated on a modest and minor, geographically remote and peripheral, natural resources scarce, and climatically exposed continent of Europe) were more focused, obsessively organized and "goal-oriented" (including the invention of virtue out of necessity - a nationstate). No wonder that European civilization has never ever generated a single religion (although it admittedly doctrinated, 'clergified' and headquartered the Middle East-revelled religion of Christianity). On the other hand, no other civilization but the European has ever created a significant, even a relevant political ideology.

This work is at first published in Bahasa language, Jakarta 2011 (Seputar Indonesia). Its advanced version was published in Italian language, 


\section{Political science}

Rome 2013 (IsAG-Rome), and by the Foreign Policy Journal of Malaysia, Kuala Lumpur 2013 (JDFR). The first English language version was published by the Routledge/Francis \& Taylor and IAFOR (London Washington 2013). This is yet, unpublished, expanded version of the text prepared for the $100^{\text {th }}$ anniversary.

\author{
* All displayed maps per the author's idea made by \\ Anneliese Gattringer. \\ ** All displayed maps per the author's idea made \\ by Anneliese Gattringer. \\ *** The 100-years anniversary poster made by \\ Amna Mahić.
}

\section{References:}

1. Dizdar, M. (1971), Stone Sleeper (org. Kameni Spavač), Svjetlost Sarajevo

2. Toynbee, A. J. (1934-61), A Study of History, Vol VII: Universal States; Universal Churches (Oxford University Press 1954) and Vol XII: Reconsiderations (Oxford University Press 1961)

3. McBrien, R. (2000), Lives of the Popes, Harper San Francisco

4. Bajrektarević, A. (2013), Future of Europe (Of Lisbon and Generational Interval), EU Journal Europe's World, Brussels

5. Kissinger, H. ( 1994), Diplomacy, A Touchstone Book

6. Siedentop, L. (2001), Democracy in Europe, Penguin Books

7. Bruton, J. (2013), How real is the danger of an EU collapse?, EU Journal Europe's World 23(13) 2013, Brussels

8. Brzezinski, Z. (1997), The Grand Chessboard, Basic Books (Perseus);

9. Leonard, M. (2005), Why Europe Will Run the 21st century, Fourth Estate London

10. Fukuyama, F. (2012), The Future of History, Foreign Affairs Magazine 91(1) 2012

11. Bajrektarević, A. (2007), Verticalization of Historical Experiences: Europe's and Asia's Security Structures Structural Similarities and Differences, Crossroads - the Macedonian Foreign Policy Journal, 4 (1), page 111112, M-MFA07.

12. Friedman, G. (2009), The Next 100 Years, Anchor Books/Random House NY;

13. Čengic, E. (1985), S Krležom iz dana u dan I - IV, Globus Zagreb Rad Beograd Svjetlost Sarajevo

14. Winder, S. (2014), Danubia - A Personal History of Habsburg Europe, Barnes \& Noble

15. Ferguson, N. (2005), Colossus - The Rise and Fall of the American Empire, Penguin Books (page 255)

16. Bajrektarević, A. (2005), Green/Policy Paper Submitted to the closing plenary of the Ministerial (Chairmanship summarizing the recommendations and conclusions of the OSCE Ministerial Summit Prague 2005), OSCE Documents/EEA 2005/05/14857/En

17. Clark, C. (2013), The Sleepwalkers: How Europe Went to War in 1914, HarperCollins Publishers

18. Mahbubani, K. (2008), The New Asian Hemisphere, Public Affairs, Perseus Books Group (page: 44-45)

19. Stiglitz, J.E. (2012), The Price of Inequality, Penguin Economics

20. Bajrektarević, A. (2013), Da Lisbona a Barcellona: Tutti gli strumenti dimenticati dell' Unione Europea, Geopolitica Rivista dell'Istituto di Alti Studi in Geopolitica e Scienze Ausiliarie, Rome

21. Wallerstein, I. (1999), The End of the World as We Know it: Social Science for the XXI century, Minneapolis: University of Minnesota Press

22. Ignatieff, M. (2003), Empire lite: Nation-Building in Bosnia, Kosovo and Afghanistan, Vintage (page 70)

23. Kafija Pruščak, H. (1596), Universal theory of the global governing wisdoms (Usul Al-hikam fi nizami-el-alem, org. Temelji mudrosti o uređenju svijeta), taken from: Imamovic, M. (1998), Historija Bošnjaka (History of Bosniaks), BZK-Preporod, Sarajevo

24. Youngs, R. (2011), Europe's Decline and Fall - The struggle against global irrelevance, Profile Books

25. Garton Ash, T. (2012), The Crisis of Europe - How the Union Came Together and Why It's Falling Apart, Foreign Affairs Magazine 91(5) 2012

26. Maalouf, A. (2009), Le Dérèglement du monde : Quand nos civilisations s'épuisent, Grasset, Paris

27. Mead, W.R. (2014), The Return of Geopolitics - The Revenge of the Revisionist Powers, Foreign Affairs Magazine 93(2) 2014

28. Bajrektarević, A. (2013), Multiculturalism is D(r)ead in Europe - MENA Oil and the (hidden) political prize Europe pays for it, Nordic Page, Oslo Norway

29. Ikenberry, G.J. (2014), The Illusion of Geopolitics, Foreign Affairs Magazine 93(3) 2014

30. Kagan, R. (2004), Of Paradise and Power, Vintage Books (page 85) 


\section{Bajrektarevic A.}

\section{References (transliterated):}

1. Dizdar, M. (1971), Stone Sleeper (org. Kameni Spavač), Svjetlost Sarajevo

2. Toynbee, A. J. (1934-61), A Study of History, Vol VII: Universal States; Universal Churches (Oxford University Press 1954) and Vol XII: Reconsiderations (Oxford University Press 1961)

3. McBrien, R. (2000), Lives of the Popes, Harper San Francisco

4. Bajrektarević, A. (2013), Future of Europe (Of Lisbon and Generational Interval), EU Journal Europe's World, Brussels

5. $\quad$ Kissinger, H. ( 1994), Diplomacy, A Touchstone Book

6. Siedentop, L. (2001), Democracy in Europe, Penguin Books

7. Bruton, J. (2013), How real is the danger of an EU collapse?, EU Journal Europe's World 23(13) 2013, Brussels

8. Brzezinski, Z. (1997), The Grand Chessboard, Basic Books (Perseus);

9. Leonard, M. (2005), Why Europe Will Run the 21st century, Fourth Estate London

10. Fukuyama, F. (2012), The Future of History, Foreign Affairs Magazine 91(1) 2012

11. Bajrektarević, A. (2007), Verticalization of Historical Experiences: Europe's and Asia's Security Structures Structural Similarities and Differences, Crossroads - the Macedonian Foreign Policy Journal, 4 (1), page 111112, M-MFA07

12. Friedman, G. (2009), The Next 100 Years, Anchor Books/Random House NY;

13. Čengic, E. (1985), S Krležom iz dana u dan I - IV, Globus Zagreb Rad Beograd Svjetlost Sarajevo

14. Winder, S. (2014), Danubia - A Personal History of Habsburg Europe, Barnes \& Noble

15. Ferguson, N. (2005), Colossus - The Rise and Fall of the American Empire, Penguin Books (page 255)

16. Bajrektarević, A. (2005), Green/Policy Paper Submitted to the closing plenary of the Ministerial (Chairmanship summarizing the recommendations and conclusions of the OSCE Ministerial Summit Prague 2005), OSCE Documents/EEA 2005/05/14857/En

17. Clark, C. (2013), The Sleepwalkers: How Europe Went to War in 1914, HarperCollins Publishers

18. Mahbubani, K. (2008), The New Asian Hemisphere, Public Affairs, Perseus Books Group (page: 44-45)

19. Stiglitz, J.E. (2012), The Price of Inequality, Penguin Economics

20. Bajrektarević, A. (2013), Da Lisbona a Barcellona: Tutti gli strumenti dimenticati dell' Unione Europea, Geopolitica Rivista dell'Istituto di Alti Studi in Geopolitica e Scienze Ausiliarie, Rome

21. Wallerstein, I. (1999), The End of the World as We Know it: Social Science for the XXI century, Minneapolis: University of Minnesota Press

22. Ignatieff, M. (2003), Empire lite: Nation-Building in Bosnia, Kosovo and Afghanistan, Vintage (page 70)

23. Kafija Pruščak, H. (1596), Universal theory of the global governing wisdoms (Usul Al-hikam fi nizami-el-alem, org. Temelji mudrosti o uređenju svijeta), taken from: Imamovic, M. (1998), Historija Bošnjaka (History of Bosniaks), BZK-Preporod, Sarajevo

24. Youngs, R. (2011), Europe's Decline and Fall - The struggle against global irrelevance, Profile Books

25. Garton Ash, T. (2012), The Crisis of Europe - How the Union Came Together and Why It's Falling Apart, Foreign Affairs Magazine 91(5) 2012

26. Maalouf, A. (2009), Le Dérèglement du monde : Quand nos civilisations s'épuisent, Grasset, Paris

27. Mead, W.R. (2014), The Return of Geopolitics - The Revenge of the Revisionist Powers, Foreign Affairs Magazine 93(2) 2014

28. Bajrektarević, A. (2013), Multiculturalism is D(r)ead in Europe - MENA Oil and the (hidden) political prize Europe pays for it, Nordic Page, Oslo Norway

29. Ikenberry, G.J. (2014), The Illusion of Geopolitics, Foreign Affairs Magazine 93(3) 2014

30. Kagan, R. (2004), Of Paradise and Power, Vintage Books (page 85) 